\title{
2019 Yılı Ağrı İli, Eleşkirt İlçesi Yüzey Araştırması ve Bir Değerlendirmesi ${ }^{1}$
}

\author{
Yavuz GÜNAȘDI ${ }^{2}$ ve İshak KÜÇÜKYILDIZ ${ }^{3}$
}

$\ddot{O} z$

Ağrı ilinin batısında yer alan Eleşkirt ilçesi, önemli yol güzergâhları üzerinde bulunur. Pirabat ve Toprakkale, ilçenin şimdiye kadar bilinen en eski yerleşim yerleridir. Ayrıca Pirabat ve Toprakkale'de bulunan yazıtlar, MÖ I. binde bölgedeki Urartu hâkimiyetini göstermektedir. 2019 yılında ilçede, Kültür Varlıkları ve Müzeler Genel Müdürlügünün izni ile yüzey araştırması yapılmıştır. Bu sayede bölge ve ilçe tarihine katkı sağlamak amaçlanmıstır. Eleşkirt Kaymakamlığı'nın destekleriyle 17-29 Eylül tarihleri arasında büyük bir kısmını ilçenin batısında yürüttüğümüz çalışmalarda 11 merkezde incelemede bulunulmuştur. Bu merkezlerden Sadaklı Höyük 2007 yllında, Hazinetepe Kalesi ise 2018 yılında I. dereceden arkeolojik sit alanı olarak tescil edilmiştir. Ancak 9 merkez ilk kez kayıt altına alınmış ve tescili için çalışmalar başlatılmıştır. Bu merkezler; Güneykaya Kalesi, Çatalpınar Kaya Sığınağı, Çatalpınar Yerleşmesi, Harami Taşlar Kalesi, Tahir (Kargaşan) Kalesi, Sarıcan Kalesi, Gülşah Kalesi ve Yerleşim Alanı, Dikentepe Kalesi ve Mendek Yerleşmesidir. Araştırmalar sırasında mimari verilerin yanında çok sayıda keramik verisi elde edilmiştir. Keramik verileri ağırlıklı olarak İlk Tunç Çă̆, Erken Demir Çağ, Orta Demir Çağ (Urartu), Geç Demir Çağ ve Orta Çağ dönemlerine aittir. Yüzey araştırmaları sırasında işlenmiş taş aletler de bulunmuştur. Bunlar üzerinde ayrıntılı çalışmalar yapılmaktadır. Kaçak kazıların yoğunluğu oldukça endişe vericidir.

Anahtar Kelimeler: Ağrı, Eleşkirt, Yüzey Araştırması, Tunç Çă̆, Demir Çă̆

\section{Year Ağr1 Province, Eleşkirt District Survey and Evaluation}

\begin{abstract}
Located in the west of Ağr1 province, Eleşkirt district is located on important road routes. Pirabat and Toprakkale are the oldest known settlements of the district until now. In addition, the inscriptions found in Pirabat and Toprakkale show the dominance of Urartian in the region in the 1 st millennium BC. A survey was conducted in the district in 2019 with the permission of the General Directorate of Cultural Heritage and Museums. In this way, it is aimed to contribute to the history of the region and the district. 11 centers were inspected in the works, most of which were carried out in the west of the district between 17-29 September with the support of the Eleşkirt District Governorship. Among these centers, Sadaklı Mound was registered as 1st degree archaeological site in 2007 and Hazinetepe Castle in 2018. However, 9 centers have been registered for the first time and studies have been initiated for registration. These centers; Güneykaya Castle, Çatalpınar Rock Shelter, Çatalpınar Settlement, Harami Taşlar Castle, Tahir (Kargaşan) Castle, Sarıcan Castle, Gülşah Castle and Settlement Area, Dikentepe Castle and Mendek Settlement. During the researches, besides the architectural data, many ceramic data were obtained. Ceramic data mainly belong to the Early Bronze Age, Early Iron Age, Middle Iron Age (Urartian), Late Iron Age and Middle Ages. Worked stone tools were also found during the surveys. Detailed studies are carried out on them. The intensity of illegal excavations is very worrying.
\end{abstract}

Key Words: Ağr1, Eleşkirt, Survey, Bronze Age, Iron Age

\section{Atıf İçin / Please Cite As:}

Günaşdı, Y. ve Küçükyıldız, İ. (2021). 2019 yılı Ağrı ili, Eleşkirt ilçesi yüzey araştırması. Manas Sosyal Araştırmalar Dergisi, 10(1), 557-577.

\footnotetext{
1 “Ağrı İli, Eleşkirt İlçesi Kalkolitik, Tunç ve Demir Çağları Yüzey Araştırması” isimli proje Kültür Varlıkları ve Müzeler Genel Müdürlüğü'nün izinleri ile gerçekleştirilmiştir [(Proje No: YA010402(2019)]. Ayrıca projeye Türk Tarih Kurumu maddi destek sağlamıştır.

2 Doç. Dr. - Atatürk Üniversitesi, Edebiyat Fakültesi, gunasdi@atauni.edu.tr

iD ORCID: 0000-0001-7955-3756

${ }^{3}$ Doktorant - Atatürk Üniversitesi, Türkiyat Araştırmaları Enstitüsü ishakkucukyildiz@hotmail.com

(D) ORCID: 0000-0002-2720-9408
} 


\section{Giriş}

Kültür ve Turizm Bakanlığı, Kültür Varlıklar1 ve Müzeler Genel Müdürlügü’nün 94949537-161.01674813 sayllı ve 16 Ağustos 2019 tarihli izni ile Y. Günaşdı başkanlığındaki ekip ile birlikte 17-29 Eylül 2019 tarihleri arasında "Ağrn İli, Eleskkirt İlgesinde, Kalkolitik, Tunç ve Demir Cağlar Yü̈ey Arasstrması" çalışmalarının ilk etabı yapılmış ve başarı ile tamamlanmışır.

Ağrı ilinin 35 km batısında yer alan Eleşkirt ilçesi, Doğu Anadolu Bölgesi'nin Yukarı Murat-Van Bölümü’nde, $1700 \mathrm{~m}$ rakımda yer almaktadır. Eleşkirt ilçesinin yüzölçümü $1307 \mathrm{~km}^{2}$ dir. İlçe, kendi adıyla anılan ova üzerine kurulmuştur. İlçenin doğusunda idari olarak bağgl olduğu Ağrı ili, güneyinde Tutak ilçesi, batısında Erzurum iline bağlı Karayazı ilçesi ile kuzeybatısında Horasan ilçesi, kuzeyinde Kars iline bağlı Kağızman ve Sarıkamış ilçeleri yer almaktadır. Eleşkirt ilçesi, batısında Tahir Dağları, kuzeyinde Kösedağ ve Karasu-Aras Dağlarının bir bölümü olan Taşkom ve Göcür Dağları, güneyinde ise Çakmak Dağlarının uzantılarıyla çevrilidir. Bölgenin en önemli su kaynağı Çakmak Dağları'ndan kaynağını alan ve Murat Nehri’nin önemli kollarından biri olan Güzeldere (Şeryan) akarsuyudur (Girgin, 1991, s. 3 vdd.; Teyfur, 1999, s. 1 vdd.).

Gürbulak sınır kapısında başlayıp Erzurum, Sivas ve Trabzon limanına bağlanan karayolu Eleşkirt ilçesinden geçmektedir. Urartu başkenti Van'dan başlayan yol ise sırasıyla; Keçikıran - Deliçay - Erciş Ağr1 Gediği - Dedeli - Değirmendüzü - Giriktepe - Patnos - Ağr1 - Eleşkirt - Tahir Gediği - Horasan Pasinler üzerinden Erzurum'a ulaşır. Bu yol güzergâhında Eski Çağ'da ve sonraki dönemlerde kullanılan oldukça önemli merkezlerin olduğu bilinmektedir. Geçmişten günümüze kadar kullanılan ve Erzurum üzerinden Tebriz'e ulaşan yol ağı batı yönünden Trabzon - Gümüşhane - Bayburt - Erzurum - Hasankale Tahir Geçidi - Eleşkirt - Ağrı - Taş̧ıı̧ay - Doğubayazıt üzerinden gelerek Kuzeybatı İran’a ulaşmaktadır (Ceylan, 2015, s. 77-78; Ceylan ve Günaşdı, 2018, s. 55 vd.; Ceylan, N., 2016, s. 656 vd.).

İlçede tarihi ve arkeolojik araştırmaların oldukça yetersiz olduğu bilinmektedir. Yüzey araştırmaları sayesinde Eleşkirt ilçesinin tarihini Geç Kalkolitik Çağdan başlatmak mümkündür. Toprakkale ve Pirabat, ilçenin bilinen en eski yerleşim yerleridir. Pirabat ve Toprakkale'de bulunan yazıtlar, MÖ I. binde bölgedeki Urartu hâkimiyetini göstermektedir (Dinçol, 1989, s. 137 vd.; Payne, 1996, s.415 vd.; Payne ve Ceylan, 2003: $191 \mathrm{vd}$.).

Pirabat Kalesi, ilçe merkezinin 17 km güneydoğusundaki Pirabat köyünde bulunmaktadır. Zeminden yüksek bir tepede kurulan kale, Aşağı Anzaf Kalesi’ne benzemektedir (Belli-Ceylan, 2004, s. 29 vd.; BelliCeylan, 2005, s. 175 vd.). N. Başgelen tarafindan tespit edilen, ev ve bahçe duvarlarında kullanılmış tüm bir yazıt ve iki yazıt parçasının burada bulunmuş olması önemlidir (Başgelen, 1985: s. 16; Dinçol, 1989, s. 137139). Bu yazıtlar daha sonra A. Ceylan tarafindan Erzurum Müzesi’ne kazandırılmıştır (Payne ve Ceylan, 2003, s. 191 vd.; Payne ve Ceylan, 2011, s. 190 vd.). Yazitta;

'Tanr Haldi'nin kudretiyle Isspuini oğlu Minua bu

kaleyi kusursuz bir şekilde yaptırd. İspuini oğlu

Minua, güclü kral, büÿ̈̈k kral, Biainili Ülkesi'nin

kral ve Tuspa Şehri'nin kahramanıdır" ifadesi geçmektedir.

Toprakkale Höyük ise ilçe merkezinin 14 km kuzeybatısında bulunmaktadır. Burada yapılan incelemelerde Urartu dönemine ait bulgulara rastlanmamıştır. Ancak Toprakkale Höyüğünün hemen yakınında, eski köy okulunun inşası sırasında bulunan Urartu yazıtı dikkat çekicidir. Tutulan raporlara göre, bu yazıt, Pirabat köyünün hemen yakınlarında bulunan, yeni ismi Körpeçayır olan Şinezir köyünden getirilmiştir. A. Ceylan ve M. R. Payne’ye göre bu yazıt aslında Pirabat'tan getirilmiş ve oradaki yazıtın bir kopyasıdır. Bir diğer görüss ise bu yazıtın İşpuini ve Menua'nın kuzeye yaptıkları seferlerden bahseden Surp Pogos ve Kasımoğlu yazıtları ile aynı olduğudur (Payne ve Ceylan, 2003, s. 196-197; Payne, 2006, s. 35-38). Yazıtta;

\footnotetext{
"Tann Haldi, kendi mıærağgyla sefere çıtı ....

Tann Haldi güclï, Tanr Haldinin mıશră̆g da

güclüdür. ... Sarduri oğlu Isphini ve Isphiini oğlu
} 
Minua ... Anaşe şehrine kadar ilerlediler ...” ifadesi geçmektedir (Marr, 1921, s. 51-60; Lehmann-Haupt, 1928-35, no. 28; Melikishvili, 1960, no. 23; Köniq, 1955-57, no. 6b; Payne ve Ceylan, 2003, s. 196-197; Payne, 2006, s. 38).

$\mathrm{Bu}$ yazıtlar ile birlikte çevredeki diğer yazıtlar da incelendiğinde çeşitli lokalizasyon sorunları ortaya çıkmıştır. Bunlardan ilki Sureli bölgesidir. II. Rusa dönemine kadar Urartu kralları kendilerini "Bianili ve Sureli Bölgesinin Kralları" olarak tanıtmışlardır. Yazıtların incelenmesiyle Sureli bölgesinin Yukarı Murat Havzasında, Ağrı Ovasında olması muhtemeldir. Pirabat ve Surp Pogos yazıtı 1şı̆ı̆ında Sureli bölgesinin Viteruhi, Lusa ve Katarza kabilelerinin yerleşkesi olduğu ayrıca Anaşe şehri ve Kuquru şehirlerini içine aldığ1 düşünülebilir (Payne ve Ceylan, 2003, s. 197 vd.).

Yazıtlarda geçen Anaşe şehri hakkında farklı lokalizasyon önerileri vardır. Bunlar Toprakkale Höyük ve Pirabat Kalesidir. Bu konuda bize bilgi veren üç yazıt vardır. Birinci yazıt Surp Pogos yazıtıdır. Van şehrindeki Surp Pogos kilisesindeki bazalt bir stelin ön ve arka yüzüne yazılmışır. Yazıtın üst kısmı Van müzesinin bahçesinde sergilenmektedir. Yazıtta;

"Efendi Tanr Haldi'ye Sarduri oğlu İspuini ve İspuini oğgu Minua bu steli diktirdiler. Tanr Haldi, kendi mı̨rağgyla sefere çıktı, Uiterubi boyunu yendi, Lusa boyunu yendi ve Katarza boyunu yendi. Tanr Haldi güclï

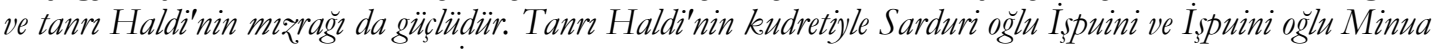
Lusa boyuna karşı sefere çlktllar. Isppuini gücliüydü ve Minua gücslïydü. Orduda 66 savas arabası, X bin 460 süvari ve 15.760 piyade (vardl). Tanr Haldi, Sarduri oğlu Isphimi ve Isspuini oğlu Minua'nnn önünden gitti. (Onlar,) Lusa ve Katarza boylarm püskërttüler... Anaşe Şebri'ne doğru ve büyü̈. Kuquru Şebrine doğru ilerlediler. Uiterubi, Lusa ve Katarza boylanna... Etiubi Ülkesinin krallarndan takviye birlikleri yardma geldiler. Tanr Haldi, kendi mąrağyla Uiterubi, Lusa ve Katarz̧a boylarna ve Etiubi Ülkesinin krallarna

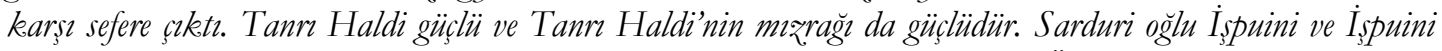
oğhu Minua sefere çlktllar, Uiterubi, Lusa ve Katarza boylarm ve Etiubi Ülkesinin kerallarmm takviye birlikelerini püskürttïler. ... Oradan Anase Sebri'ne geldiler. X bin 720 erkek, X bin 670 kadin, X yüz 26 at, 13.540 büyükbas hayvan, $20.785 \ldots$... (2x)

Her kim bu yazıta karşı suç işlerse, her kim (buradan) çalarsa, her kim gömerse, her kim suya atarsa, her kim yerini değģstirirse, her kim güneşten saklarsa, her kim bir başkasina bunlar yapturp "tabrip et" derse veya ber kim değisize bir șey, (yani) "Ben yaptım" derse; Tann Haldi, Tanr Teişeba ve Tanr Sivini (onu) bırakmasinlar. Ne adm ne de soyunu, yeryü̈ünde...” ifadesi geçmektedir (Sayce, 1882: no. 31; Melikishvili, 1960, no. 20, 22; Köniq, 1955-57, no. 6; Lehmann-Haupt, 1928-35, no. 13; Payne, 2006, s. 35-37).

İkinci yazıt mezar taşı olarak kullanılan Kasımoğlu'ndaki dikili bir taşın üst kısmında bulunmaktadır. İspuini ve Menua'nın seferlerinden bahseden bu yazıtlarda savaşı İşpuini ve Menua'nın kazandığı ve Anaşe şehrine geldiği yazılmıştır. Surp Pogos yazıtının kopyası olduğu düşünülmektedir. Yazıtta;

'Efendi Tanr Haldi'ye Sarduri oğlu İspuini ve Isspuini oğlu Minua bu steli diktirdiler. Tanr Haldi, kendi misrağgyla sefere ģıth, Uiterubi boyunu yendi, Lusa boyunu yendi ve Katarza boyunu yendi. Tanr Haldi güclï

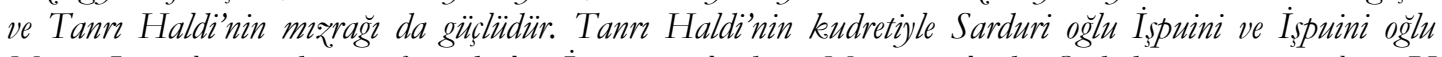

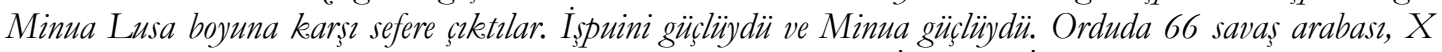
bin 460 süvari ve 15.760 piyade (vard). Tann Haldi, Sarduri oğlu Ispmini ve Ispuini oğhu Minua'nm önünden gitti. ...” ifadesi geçmektedir (Lehmann-Haupt, 1928-35, 35 res. 4 ve no. 14; Melikishvili, 1960, no. 21; Köniq, 1955-57, no. 6a; Payne, 2006, s. 37).

Toprakkale'de bulunan üçüncü yazıtta da kralların Anaşe şehrine geldiği belirtilmiştir. Toprakakle'de bulunan yazıtla Anaşe şehrinin burası olduğu düşünülmüştür. Ancak yukarıda da belirttiğimiz gibi yazıt Toprakkale'de bulunmamıştır. Yazıt Pirabat köyü yakınlarında bulunan Şinezir köyünden getirilmiş olup, orijinal yerinin Pirabat olduğu düşünülmektedir. Peki, Anaşe şehri Pirabat mıdır? Eldeki verilerle bunu söylemek şu an için pek mümkün görülmemektedir. Yazıtlarda Anaşe şehrinin İşpuini ve Menua tarafından ele geçirildiği de tam olarak anlaşılamamaktadır. Ancak şehir Pirabat Kalesi'nin yakınında, muhtemelen kuzeyinde bir bölgede kurulmuştur (Payne ve Ceylan, 2003, s.197 vd.). Bölgede devam ettirdiğimiz yüzey araştırmaları, bu sorunun cevabını verebilmek adına oldukça önemlidir.

\section{Bulgular}

Arazi çalışmalarına başlamadan önce 25.000'lik haritalar üzerinde incelemeler yapıllmış ve daha önce yapılan araştırmalar ve yayınlar gözden geçirilmiştir. İlçedeki kurumların desteği alınmış ve çalışmalar 
hakkında bilgi verilmiştir. Bu noktada hiçbir yardımını esirgemeyen Eleşkirt Kaymakamı Gülhani Ozan SARI'ya, Eleşkirt İlçe Jandarma Komutanlığı'na, arazi çalısmaları sırasında ve sonrasında desteklerini fazlasiyla gördüğümüz Mehmet Sait YAZICI'ya ve bölge halkına teşekkür ederiz.

2019 yılında başlamış olduğumuz çalışmaların ilk etabında 11 sit alanında incelemede bulunulmuştur (Harita 1). Bu merkezlerden Sadaklı Höyük 2007 yllında, Hazine Tepesi Kalesi ise 2018 yllinda I. dereceden arkeolojik sit alanı olarak tescil edilmiştir. Diğer merkezlerde ilk kez bilimsel çalışmalar yapılmış ve tescilleri için gerekli çalışmalar başlatılmıştır. Araştırmalar, Eleşkirt ilçesinin oldukça zengin olduğunu göstermiş ve ilerleyen dönemlerde yapacağımız çalışmaların da oldukça verimli geçeceğine işaret etmiştir.

\section{Güneykaya Kalesi}

Güneykaya Kalesi, Ağrı ili, Eleşkirt ilçesinin 10 km batısında, Güneykaya köyünün 500 m batısında, $2160 \mathrm{~m}$ rakımda yer almaktadır (Foto 1-2). Tahir Geçidi'nin Eleşkirt Ovasına açılan son noktasındadır. Hem Eleşkirt Ovası'nı hem de boğazı kontrol etmesi açısından oldukça önemli bir kaledir. Bölgenin en önemli su kaynağı olan Güzeldere (Şeryan) Çayı'nın hemen kuzeyindedir. Ayrıca güneyine doğru açılan vadiyi kontrol etmektedir. Güneykaya Kalesi, kuzey-güney doğrultulu $22 \mathrm{~m}$, doğu-batı doğrultulu ise $17 \mathrm{~m}$ boyutlarındadır. Oldukça sarp, doğal bir tepenin üzerinde yer alan kale, zeminden $340 \mathrm{~m}$ yüksektedir. Kalenin doğusu, güneyi ve batısı uçurumlar ile çevrilidir. Kalenin giriş kapısı kuzeydoğusunda yer almaktadır. Kapı genişliği 1 m'dir. Kaleye ulaşımın en kolay olduğu yer de burasıdır. Kalenin kuzeybatısında ilk tespit ettiğimiz alanlardan biri kaya basamaklı su tüneli olduğunu düşündüğümüz yapıdır. 1,5 m uzunluğunda ve $80 \mathrm{~cm}$ genişliğindeki bu yapının ölçülebilen derinliği ise 1,5 m’dir. $\mathrm{Bu}$ yapının içerisi günümüzde taş ve toprak ile dolduğundan işlevi tam olarak anlaşılamamıştır. Yapı, su sarnıc1 veya silo olarak da kullanılmış olabilir. Bu yapının hemen batı tarafında sur duvar izleri göze çarpmaktadır. Bu sur duvarı doğu - batı doğrultulu uzanmaktadır. Kalenin özellikle kuzey tarafında Urartu dönemine ait olduğunu düşündüğümüz duvar izlerine rastlanmaktadır. Ayrıca kalenin hemen üzerinde oldukça tahrip olmuş ancak yer yer 4-5 m yüksekliğine varan Orta Çağ dönemine ait sur duvarları da mevcuttur. Kalenin hemen üzerinde su sarnıc1 veya silo olarak kullanıldığını düşündügümüz başka bir yapı da dikkati çekmektedir. Bu yapı, 1,70 m uzunluğunda ve $1 \mathrm{~m}$ genişliğindedir. Yüzey araştırmasının yapıldığı dönemde yapının içerisi su ile dolu olduğundan derinliği hakkında net bir bilgi sahibi olamadık. Ancak ölçülebilen derinliği 2 m'dir. Kalede bu tarz başka yapıların da olduğu bölge halkı tarafindan ifade edilmiştir. Ancak üzerlerinin tamamıyla kapanmış olması nedeniyle bu yapılar tespit edilememiştir. Kalenin hemen üzerinde iki tane sunak göze çarpmaktadır. Aralarında yaklaşı $50 \mathrm{~cm}$ olan bu sunakların biri $30 \mathrm{~cm}$ genişliğinde, 40 $\mathrm{cm}$ derinliğinde diğeri ise $20 \mathrm{~cm}$ genişliğinde, $25 \mathrm{~cm}$ derinliğindedir. Güneykaya Kalesi’nin hemen üzerinde anakayanın düzeltilerek oluşturulduğu anlaşılan bir açık hava tapınağı vardır. Bu tapınak alanına $70 \mathrm{~cm}$ genişliğinde, $40 \mathrm{~cm}$ yüksekliğinde ve $25 \mathrm{~cm}$ derinliğinde 7 basamak ile çıkılmaktadır. Bu basamakların 2'si tahrip olmuştur. Diğer 5 tanesi ise daha sağlam durumdadır. Tapınağın üzerinde başka kaya basamaklı alanlar da mevcuttur. Ancak bu basamaklar tahrip olduğundan sayısı ve ölçüleri tam olarak tespit edilememiştir. Kalenin kuzeybatı tarafinda Urartu dönemine ait olduğunu düşündüğümüz duvar izleri oldukça belirgindir. Duvarlar kiklopik teknikte yapılmıştır. Duvarlarda kullanılan taşların kabaca düzeltildiği görülmektedir. Kalenin çevresinde çok sayıda kaçak kazı izi vardır. Özellikle kalenin kuzeybatı tarafinda bu kaçak kazıların yoğunlaştığı görülmektedir. Güneykaya Kalesi'nin bulunmuş olduğu konum düşünüldüğ̈̈nde bölgenin en önemli kalelerinden biri olduğu anlaşılmaktadır. Özellikle kalede bulunan açık hava tapınağı, kaya basamaklı su tüneli ve sarnıçlar da bu kalenin önemini ortaya koymaktadır. Özellikle Urartu döneminin bölgedeki önemli kalelerinden biri olduğunu düşünmekteyiz. Bu bölgeye yakın diğer önemli Urartu kaleleri arasında Yazılıtaş Kalesi, Pasinler Kalesi, Avnik Kalesi vs. sayllabilir ${ }^{4}$. Stratejik konumundan dolayı daha sonraki dönemlerde de yerleşim gördüğü anlaşılan kalenin keramik verileri ìlk Tunç Çă̆, Orta Demir Çağ (Urartu) ve Orta Çă̆ dönemlerine tarihlendirilmektedir.

\section{Hazinetepe Kalesi}

Hazinetepe Kalesi, Ağr1 ili, Eleşkirt ilçesinin $14 \mathrm{~km}$ batısında, Çatalpınar köyünün 2,5 km kuzeydoğusunda, 107 ada, 30 parselde kayıtlı, mülkiyeti Maliye Hazinesine ait taşınmaz $2110 \mathrm{~m}$ rakımda yer almaktadır (Foto 3-4). Güneykaya Kalesi'nin 4 km kuzeyinde yer alan kale, Eleşkirt Ovası'nı ve boğazı kontrol etmesi açısından stratejik bir noktadadır. Tahir Geçidi’nin doğusunda ve tarihi İpek Yolu'nun güneyinde bulunan kale, su kaynakları açısından elverişli bir konumdadır. Kalenin çevresi, tarım ve hayvancillk açısından oldukça verimlidir. Zeminden yaklaşık $60 \mathrm{~m}$ yükseklikte doğal bir tepenin üzerine kurulmuştur. Hazinetepe Kalesi, daha önceden tespit edilmiş olup 2018 yllında Van Kültür Varlıklarını

${ }^{4}$ Ayrıntılı bilgi için bkz. Ceylan, A. ve Günaşdı, Y., Eræ̌urum'un Eskiçağ Kaleleri, Erzurum, 2018. 
Koruma Bölge Kurulu tarafindan I. dereceden arkeolojik sit alanı olarak tescil edilmiştir. Kale, 38 x 38 m boyutlarındadır. Kalenin özellikle doğu, güney ve batısında sur duvarları izlenebilmektedir. Sur duvarlarının kalınlığ1 1,80 m'dir. Kale duvarlarında kullanılan taşlar ortalama 60 x $40 \mathrm{~cm}, 70$ × $50 \mathrm{~cm}$ ölçülerindedir. Kalenin özellikle kuzeyindeki duvarların çok tahrip edildiği görülmektedir. Muhtemelen giriş kapısı kalenin kuzey tarafında yer almaktadır. Ancak tahribat nedeniyle giriş kapısına ait herhangi bir ize rastlanmamıştır. Kalenin doğusu, batısı ve güneyi savunma açısından daha elverişlidir. Birçok noktasında kaçak kazı izleri mevcuttur. Tespit edilen keramik verileri, İlk Tunç Çağ, Erken Demir Çağ, Orta Demir Çağ (Urartu) ve Orta Çağ’a tarihlendirilmektedir.

\section{Çatalpınar Yerleşmesi}

Çatalpınar Yerleşmesi, Ağrı ili, Eleşkirt ilçesinin $14 \mathrm{~km}$ batısında, Çatalpınar köyünün $500 \mathrm{~m}$ güneybatısında, $2050 \mathrm{~m}$ rakımda yer almaktadır (Foto 5-6). Oldukça geniş bir alana yayılan yerleşim yeri ortalama kuzey-güney doğrultulu $230 \mathrm{~m}$, doğu-batı doğrultulu ise $100 \mathrm{~m}$ 'dir. Yerleşmede çok sayıda mimari yapı görülmesine rağmen tahribat nedeniyle planları tam olarak anlaşılamamaktadır. Merkezin çevresinde çok sayıda kaçak kazı yapılmıştır. Kifiri Deresi yerleşmenin batısından geçerek güneye doğru devam etmektedir. Bu dere, Güzeldere (Şeryan) Çayının kollarından birisidir. Yerleşmenin doğusu ve kuzeyi yerleşim açısından oldukça uygundur. Güneybatı tarafi ise oldukça sarptır. Tespit edilen keramik verileri, İlk Tunç Çağ, Geç Demir Çağ, Helenistik Dönem ve Orta Çağ dönemlerine tarihlendirilmektedir.

\section{Çatalpınar Kaya Sığınağı}

Çatalpınar Kaya Sığınağı, Ağıı ili, Eleşkirt ilçesinin 14 km batısında, Çatalpınar köyünün $600 \mathrm{~m}$ güneybatısında, $1960 \mathrm{~m}$ rakımda yer almaktadır (Foto 7-8). Kaya sığınağı, Çatalpınar Yerleşmesinin ise hemen $100 \mathrm{~m}$ güneyindedir. Sığınağın hemen güneyinden Kifiri Deresi geçmektedir. Doğal bir kayalı̆̆ın kuzeybatısında, zeminden yaklaşık 50 m yükseklikte, 6 basamak ile çıkılan ve Orta Çağ'da da kullanıldığ1 anlaşılan bir kaya sığınağıdır. Kaya sığınağında aydınlatma maksatlı kullanıldığını düşündügümüz küçük boyutlu 8 adet niş vardır. Ayrıca kaya sığınağının sağ ve sol tarafında karşılıklı bir şekilde taşın oyulması suretiyle yapılmış ve halat bağlamak için kullanıldığını tahmin ettiğimiz oyuklar göze çarpmaktadır. Tahribat nedeniyle günümüzde ulaşımı oldukça zorlaşmıştır.

\section{Harami Taşlar Kalesi}

Harami Taşlar Kalesi, Ağrı ili, Eleşkirt ilçesinin $32 \mathrm{~km}$ kuzeybatısında, Tahir beldesinin $5 \mathrm{~km}$ kuzeyinde, $2210 \mathrm{~m}$ rakımda yer almaktadır (Foto 9-10). Erzurum-Ağrı il sınırında bulunmaktadır. Ağrı’yı Erzurum'a bağlayan eski İpek Yolu'nun hemen doğu tarafındadır. Kale, kuzeyinde bulunan vadiyi kontrol etmektedir. Bu vadi Erzurum Horasan ilçesinin köyleri ile bağlantıyı sağlamaktadır. Kalenin $3 \mathrm{~km}$ kuzeydoğusunda önemli bir Urartu kalesi olduğunu bildiğimiz Erzurum’un Horasan ilçesinde bulunan Hasanbey Kalesi yer almaktadır ${ }^{5}$. Kale, kuzeybat1-güneydoğu doğrultuludur. Kalenin doğusu, güneyi ve kuzeybatısı tarım arazileriyle çevrilidir. Tarım arazileri kaleyi kısmen tahrip etmiştir. Kalenin hemen batısından Bozsu deresi geçmektedir. Bu derenin Aras Nehrinin kollarından birisi olduğu anlaşılmaktadır. Ayrıca kalenin hemen doğu tarafinda da küçük bir derenin bulunduğu görülmektedir. Kalenin doğusunda ve kuzeyinde mimari yapı izleri göze çarpmaktadır. Özellikle doğu, batı ve güney tarafta bulunan taşlar doğal sur görünümündedir. Kale, kuzeybatt-güneydoğu doğrultulu $87 \mathrm{~m}$, kuzeydoğu-güneybatı doğrultulu ise $50 \mathrm{~m}$ ölçülerindedir. Çok sayıda kaçak kazı izi vardır. Tespit edilen keramik verileri, İlk Tunç Çağ ve Orta Çağ’a tarihlendirilmektedir. Ayrıca işlenmemiş obsidiyen buluntuları da mevcuttur.

\section{Tahir (Kargaşan) Kalesi}

Tahir Kalesi, Ağrı ili, Eleşkirt ilçesinin 32 km kuzeybatısında, Tahir beldesinin 500 m güneybatısında, 2210 m rakımda yer almaktadır (Foto 11-12). Kale, köyün hemen batısında doğal bir kayalık üzerinde, Erzurum-Ağrı karayolunun doğusunda, bölgeyi kontrol altında tutacak bir noktadadır. Kalenin kuzeybatısında tarihi İpek Yolu bulunmaktadır. Tahir Kalesi'nin hemen batısından Kargaşan Çayı geçmektedir. Kale, doğu-batı doğrultulu $50 \mathrm{~m}$, kuzey-güney doğrultulu $39 \mathrm{~m}$ boyutlarındadır. Kale sur duvarlarına ve mimari yapılara ait taşların köy evlerinin yapımında kullanıldığı anlaşılmaktadır. Bu nedenle sur duvarları ve mimari yapılar oldukça tahrip olmuştur. Ancak güneydoğu tarafinda yer yer duvar izleri takip edilebilmektedir. Kaçak kazıların yoğun bir şekilde görüldüğü kale, keramik verisi açısından oldukça 
zengindir. Tespit edilen keramik verileri, İlk Tunç Çă̆g, Orta Demir Çağ (Urartu), Geç Demir Çağ ve Orta Çağ'a tarihlendirilmektedir.

\section{Sarican Kalesi}

Sarıcan Kalesi, Ağr1 ili, Eleşkirt ilçesinin 18 km batısında, Sarıcan köyünün 500 m güneyinde, 2140 m rakımda yer almaktadır (Foto 13-14). Erzurum-Ağrı yolunun hemen batısında, yolu kontrol etmek amacıyla yapılmış önemli bir kaledir. Kalenin kuzeyinden gelerek güneyini dolaşan Güzeldere (Şeryan) Deresi bölgenin en önemli su kaynağıdır. Doğu-batı doğrultulu kurulan kale 36 x 12 m boyutlarındadır. Özellikle kalenin güneydoğu ve güneybatısında sur duvar izleri görülmektedir. Tespit edilen bu duvarlar 2 m genişliğindedir. Duvarlarda kullanılan taşların ön yüzeyleri kabaca düzeltilmiştir. Duvarların yapımında kiklopik tekniğin kullanıldığ1 görülmektedir. Kalenin güney tarafı yüksek dağlarla çevrilidir. Kalenin hemen kuzeybatı tarafinda TRT vericileri bulunmaktadır. Karakol niteliğinde yapıldığı anlaşılan kalenin çevresinde çok sayıda kaçak kazı izi vardır. Keramik verisi açısından oldukça zengindir. Tespit edilen keramik verileri, İlk Tunç Çă̆, Orta Demir Çağ (Urartu) ve Orta Çağ’a tarihlendirilmektedir.

\section{Sadaklı Höyük}

Sadaklı Höyük, Ağıı ili, Eleşkirt ilçesinin 7 km güneydoğusunda, Sadaklı köyünün 100 m güneyinde, $1730 \mathrm{~m}$ rakımda yer almaktadır (Foto 15-16). Daha önceden tespit edilmiş olup 03.05.2007 tarihinde Erzurum Kültür ve Tabiat Varlıklarını Koruma Bölge Kurulu tarafindan 1. dereceden sit alanı ilan edilerek koruma altına alınmıştır. Höyüğün hemen kuzeyinden Erzurum-Ağr1 yolu geçmektedir. Höyük, yolun yaklaşık 100 m güney tarafında, Eleşkirt Ovası'nın üzerindedir. Çevresi tamamıyla tarım arazileriyle çevrilidir. Murat Nehri'nin kollarından biri olduğu anlaşılan dere, höyüğün hemen $100 \mathrm{~m}$ güneyinden geçmektedir. Yakın bir zamanda höyügün tepesinde bulunan 2 tane yüksek gerilim hattının yerinden çıkarılarak höyüğün batı eteğine konulduğu anlaşılmıştır. Höyükte, yoğun kaçak kazı izleri görülmektedir. Keramik verisi açısından oldukça zengindir. Tespit edilen keramik verileri, İlk Tunç Çağ (kaliteli Karaz keramiği de mevcuttur), Erken Demir Çağ ve Orta Demir Çağ’a (Urartu) tarihlendirilmektedir. Konum olarak her türlü tahribata açık olmasından dolayı acil koruma altına alınması gerekmektedir.

\section{Gülşah Kalesi ve Yerleşim Alanı}

Gülşah Kalesi ve Yerleşim Alanı, Ağrı ili, Eleşkirt ilçesinin 25 km batısında, Karabacak köyünün 3 km güneybatısında, $2430 \mathrm{~m}$ rakımda yer almaktadır (Foto 17-18). Bölgenin en yüksek ve en önemli kalelerinden birisidir. Kale, Erzurum-Ağrı karayolunun güneyinde, 10 köyü kuş bakışı görebilecek noktadadır. Kalenin hemen kuzeyinden Güzeldere (Şeryan) Çayı geçmektedir. Kalenin doğu tarafinda da küçük bir su kaynağı bulunmaktadır. Kalenin kuzeyi ve batısı verimli tarım arazileriyle, doğusu ve güneyi ise yüksek dağlarla çevrilidir. Erzurum-Ağrı karayolunu ve bölgeyi kontrol eden stratejik bir kaledir. Gülşah Kalesi, kuzeybatı-güneydoğu doğrultulu $50 \mathrm{~m}$, kuzeydoğu-güneybatı doğrultulu ise $37 \mathrm{~m}$ boyutlarındadır. Zeminden yaklassık $200 \mathrm{~m}$ yüksektedir. Kale duvarlarının yer yer ayakta olduğu görülmektedir. Kale sur duvarlarında kullanılan taşların kalenin güneyinde bulunan kaynaklardan getirildiği anlaşılmaktadır. Sur duvarlarında kullanılan taşlar ortalama $50 \times 35 \mathrm{~cm}, 70 \times 30 \mathrm{~cm}, 60 \times 40 \mathrm{~cm}$ boyutlarındadır. Sur duvarlarının genişliği ise 1,50 m'dir. Giriş kapısı kalenin doğu tarafındadır. Kale, günümüzde ağıl olarak kullanılmaktadır. Bu yüzden kalenin mimari yapıları tam olarak izlenememektedir. Ancak yer yer kalenin orijinal mimari yapılarına rastlanmaktadır. Kalede kullanılan taşların düzeltildiği ve kiklopik teknik kullanılarak duvarlarının oluşturulduğu anlaşılmaktadır. Kurtin ve bastiyonlar dikkat çekmektedir. Kalenin kuzey eteğinde nekropol alanı, kuzeydoğu tarafinda ise yerleşim alanları vardır. Kalenin içerisi tamamıyla koyun gübresi ile kaplıdır. Bu yüzden çok fazla keramik verisi tespit edilememiş̧ir. Kalenin eteklerinden tespit edilen keramik verileri İlk Tunç Çağ ve Orta Çağga tarihlendirilmektedir. Buradaki tahribat oldukça ciddi boyuttadır.

\section{Dikentepe Kalesi}

Dikentepe Kalesi, Ağrı ili, Eleşkirt ilçesinin 18 km batısında, Sarıcan köyünün 3 km kuzeyinde, 2280 m rakımda yer almaktadır (Foto 19-20). Erzurum-Ağrı karayolunu kontrol etmek için yapılmıştır. Kuzeyinde küçük bir vadi bulunmaktadır. Doğusundan ve batısından küçük dereler akmaktadır. Kalenin çevresi yüksek tepelerle çevrilidir. Bu tepeler, kalenin savunmasını kolaylaştırmaktadır. Kalenin hemen kuzeyinde eski Erzurum-Ağrı karayolu bulunmaktadır. 1976 y1lına kadar bu yolun aktif olarak kullanıldığ1 bilinmektedir. Kale üzerinde mimari yapılar izlenebilmektedir. Özellikle doğu ucunda bulunan mimari yapının planı belirgindir. Kalede, tahribatın oldukça fazla olduğu anlaşılmaktadır. Kale duvarlarında 
kullanılan taşlar kabaca düzeltilmiștir. Kale ve çevresinde kaçak kazı izlerine rastlanılmaktadır. Araştırma sırasında tespit edilen keramik verileri, ìlk Tunç Çağ, Erken Demir Çă̆ ve Orta Çăğa tarihlendirilmektedir.

\section{Mendek Yerleşmesi}

Mendek Yerleşmesi, Ağnı ili, Eleşkirt ilçesinin $18 \mathrm{~km}$ kuzeybatısında, Sarıcan köyünün $2 \mathrm{~km}$ kuzeydoğusunda, $2180 \mathrm{~m}$ rakımda yer almaktadır (Foto 21-22). Sarıcan Kalesi'nin hemen kuzeyinde, Dikentepe Kalesi'nin ise doğusundadır. Yerleşmenin hemen kuzey tarafinda günümüzde işletilmeyen bir kömür yatağı vardır. Kuzey-güney doğrultulu bir yerleşmedir. Ortalama kuzey-güney doğrultulu 190 m, doğu-batı doğrultulu ise $100 \mathrm{~m}$ 'lik bir alana yayılmıştır. Yerleşim üzerindeki mimari yapılar yer yer görülmektedir. Bu mimari yapılardan biri kuzey-güney doğrultulu $17 \mathrm{~m}$, doğu-batı doğrultulu ise $11 \mathrm{~m}$ boyutlarındadır. Bir diğer mimari yapı ise kuzey-güney doğrultulu $13 \mathrm{~m}$, doğu-batı doğrultulu $11 \mathrm{~m}$ boyutlarındadır. Mimari yapıların duvarlarının genişliği ise 1,50 m'dir. Yerleşme keramik verisi açısından oldukça zengindir. Araştırma sırasında tespit edilen keramik verileri Orta Çağ dönemine tarihlendirilmektedir.

\section{Sonuç}

2019 yılında başlamış olduğumuz araştırmaların ilk etabı oldukça verimli geçmiştir. Çalışmalarda 11 sit alanı üzerinde incelemelerde bulunulmuştur. Bu merkezlerden 9'u ilk kez bu araştırmalarda tespit edilmiştir. Tablodaki bilgiler incelendiğinde, 9 merkezin keramik verilerine bakılarak, İlk Tunç Çağından itibaren bölgenin yoğun bir yerleşime uğradığı anlaşılır. 3 merkezde Erken Demir Çağ, 5 merkezde Orta Demir Çă̆, 2 merkezde Geç Demir Çağ ve 1 merkezde Helenistik Dönem keramik verilerine rastlanılmıştır. Güneykaya Kalesinde yer alan su sarnıçları, kaya basamaklı kutsal alan ve sunaklar bölgedeki Urartu varlığına mimari anlamda işaret etmektedir. Eski Çağ’da kullanılan merkezlerin neredeyse tamamı Orta Çağ'da da kullanılmıştır. Çalışmalarımız sırasında ilçenin tarihi geçmişini çok daha eskiye götüreceğini düşündüğümüz işlenmiş taş aletler de bulunmuştur. Bu aletler üzerinde gerekli çalışmalar yapılmaktadır. Tespit edilen merkezlerin tamamında kaçak kazı izleri mevcuttur. Bölgenin en önemli kalelerinden biri olduğunu düşündüğümüz Gülşah Kalesi’nde, kale duvarlarının önemli bir kısmı sökülerek büyük bir ağıl yapıldığ anlaşılmışıır. 2019 yılında Eleşkirt ilçesinin batısında yürüttüğümüz çalışmalar ilerleyen dönemlerde de devam edecektir. Yüzey araştırmaları sayesinde bölge tarihine 1şık tutacağını düşündüğümüz birçok merkezin daha tespit edileceğini düşünmekteyiz.

\begin{tabular}{|c|c|c|c|c|c|c|}
\hline Merkezin Adı & $\begin{array}{c}\text { İlk Tunç } \\
\text { Çağ }\end{array}$ & $\begin{array}{c}\text { Erken } \\
\text { Demir Çăg }\end{array}$ & $\begin{array}{l}\text { Orta Demir } \\
\text { Çağ }\end{array}$ & $\begin{array}{l}\text { Geç Demir } \\
\text { Çağ }\end{array}$ & $\begin{array}{c}\text { Helenistik } \\
\text { Dönem }\end{array}$ & Orta Çăg \\
\hline Güneykaya Kalesi & - & & - & & & - \\
\hline Hazinetepe Kalesi & - & - & - & & & - \\
\hline Çatalpınar Kaya Sı̆̆ınağı & & & & & & - \\
\hline Çatalpınar Yerleşmesi & - & & & - & - & - \\
\hline Harami Taşlar Kalesi & - & & & & & - \\
\hline Tahir (Kargaşan) Kalesi & - & & - & - & & - \\
\hline Sarican Kalesi & - & & - & & & - \\
\hline Sadaklı Höyük & - & - & - & & & \\
\hline Gülşah Kalesi ve Yerleşimi & - & & & & & - \\
\hline Dikentepe Kalesi & - & - & & & & - \\
\hline Mendek Yerleşmesi & & & & & & - \\
\hline
\end{tabular}

\section{Etik Beyan}

"2019 Yıl Ağr İli, Eleşkirt İlçesi Yürey Araștrması” başlıklı çalışmanın yazım sürecinde bilimsel kurallara, etik ve alıntı kurallarına uyulmuş; toplanan veriler üzerinde herhangi bir tahrifat yapılmamış ve bu çalışma herhangi başka bir akademik yayın ortamına değerlendirme için gönderilmemiştir. Bu araştırma doküman incelemesine dayalı olarak yapıldığından etik kurul kararı zorunluluğu bulunmamaktadır.

\section{Teşekkür}

Arazi çalışmalarına Prof. Dr. Alpaslan CEYLAN, Doktorant İshak KÜÇÜKYILDIZ ve bakanlık temsilcimiz Aysun ADIGÜZEL katılmıştır. Yüzey araştırması laboratuvar çalışmaları Dr. Öğr. Üyesi Gökhan KALMIŞ, Dr. Öğr. Üyesi Ayşe Nur MORKOÇ, Arş. Gör. Burak BİNGÖL, Murat ÇİFTÇİ, 
Uğur KARCIOĞLU, Betül NIŞANCI, Emine ÇALBAY, Mehmet Akif ARSLAN, Halil İbrahim YILMAZ, Nazik LAÇİNOK, Tuba ÖKSÜZ ve Ayşe KARAMAN tarafindan yürütülmüştür. Bölgede yaptığımız çalışmaların rahatlıkla yürütülmesi adına fazlasıyla desteğini gördüğümüz Eleşkirt Kaymakamı Gülhani Ozan SARI'ya, Mehmet Sait YAZICI'ya ve bölge halkına teşekkür ederiz.

\section{Kaynakça}

Başgelen, N. (1985). Doğu Anadolu'dan demir çağına ait bazı yeni bulgular kitabeler - kaya tünelleri. Arkeoloji ve Sanat 28-30, 15-18.

Belli, O. ve Ceylan, A. (2004). 2002 Yılı Anzaf Kaleleri kazı ve onarım çalışmaları. 25. Ką̧ Sonuçlar Toplantısı-II, 2940.

Belli, O. ve Ceylan, A. (2005). 2003 Yılı Anzaf Kaleleri kazı ve onarım çalışmaları. 26. Ką̧ Sonuçlar Toplantısı-I, Ankara, 175-188.

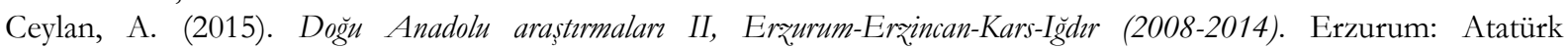
Üniversitesi Yayınları.

Ceylan, A. ve Günaşdı, Y. (2018). Erz̧urum'un Eskiçağ kaleleri. Erzurum: Atatürk Üniversitesi Yayınları.

Ceylan, N. (2016). Pasin Ovasının kuzeye açılan iki tarihi yolu. Uluslararası Sosyal Araștırmalar Dergisi 9/43, 656-671.

Dinçol A. M. (1989). Yeni Urartu yazıtları ve yazıt parçaları. Anadolu Araștırmalar 11, 137-148.

Girgin, M. (1991). Eleşkirt Ovası ve çevresinin fiziki coğrafyası (Doktora Tezi). Atatürk Üniversitesi Sosyal Bilimler Enstitüsü, Erzurum.

König, F.W. (1955-1957). Handbuch der chaldäischen inschriften. Archiv für Orientforschung.

Lehmann-Haupt, C. F. (1928-1935). Corpus inscriptionum chaldicarum I-II. Leipzig.

Marr, N. A. (1921). Fragment haldskoy nadpisi iz Alaşkerta. Izvestiya Rossiyskoy Akademiyi Istoriyi Materialnoy Kulturi (1): $51-60$.

Payne, M. R.(1996). Urartian inscriptions in Erzurum Museum. Anadolu Arasttrmalar, 14, 415-423.

Payne, M. R. (2006). Urartu çiviyaz̨ll belgeler kataloğu. İstanbul.

Payne, M. R. ve Ceylan, A. (2003). A new Urartian inscription from Ağrn - Pirabat. Studi Micenei Ed - Egeo - Anatolici, Fascicolo XLV/2, 191-201.

Payne, M. ve Ceylan, A. (2011). More inscribed Urartian stones from Erzurum Museum. SMEA, 53, $189-194$.

Sayce, A. H. (1882). The cuneiform inscriptions of Van. JRAS, 14, 377-732 (no. 1-57)

Teyfur, A. (1999). Eleşkirt ilçe merkę̧inin coğrafi etüdü (Yüksek Lisans Tezi). Atatürk Üniversitesi Sosyal Bilimler Enstitüsü, Erzurum.

Melikishvili, G. A. (1960). Urartskiye klinoobrazniye nadpisi. Moscow: Akademiya Nauk SSSR.

\section{EXTENDED ABSTRACT}

Located $35 \mathrm{~km}$ west of Ağrn, Eleşkirt district is located in the Upper Murat-Van section of the Eastern Anatolia Region at an altitude of $1700 \mathrm{~m}$. Ağr1 province is located in the east of the district, Tutak district in the south, Karayazı district in the west and Horasan, Kağızman and Sarlkamış districts in the northwest. Eleşkirt district is surrounded by Tahir Mountains in the west, Taşkom and Göcür Mountains, which are a part of Kösedağ and Karasu-Aras Mountains in the north, and extensions of Çakmak Mountains in the south. The most important water resource of the region is Güzeldere (Şeryan) stream, which takes its source from Çakmak Mountains.

Toprakkale and Pirabat are the oldest known settlements of the district. The inscriptions found in Pirabat and Toprakkale show the dominance of Urartu in the region in the 1st millennium BC. Pirabat Castle is located in the village of Pirabat, $17 \mathrm{~km}$ southeast of the district center. The castle, built on a hill high above the ground, resembles the Lower Anzaf Castle.

Toprakkale Mound is located $14 \mathrm{~km}$ northwest of the district center. In the examinations made here, no findings belonging to the Urartian period were found. However, the Urartian inscription found during the construction of the old village school near Toprakkale Mound is striking. According to the reports kept, this inscription was brought from Şinezir village, the new name of which is Körpeçayır, located in the immediate vicinity of Pirabat village. With the permission of the Ministry of Culture and Tourism, General Directorate of Cultural Heritage and Museums with the permission of 94949537-161.01-674813 and dated 16 August 2019, with the team under my presidency, between 17-29 September 2019 in "Agri Province, Eleşkirt District, Chalcolithic, Bronze and Iron Ages Survey" studies were carried out. The first phase of the research is especially concentrated in the western part of the district. In these researches, 11 site areas were examined. Among the identified centers, Sadaklı Mound was registered as a 1st degree archaeological site in 2007 and Hazinetepe Castle in 2018. Scientific research has been carried out for the first time in other centers and the necessary studies have been initiated for the registration of these centers. 
Work centers; Güneykaya Castle, Hazinetepe Castle, Çatalpınar Settlement, Çatalpınar Rock Shelter, Harami Taşlar Castle, Tahir (Kargaşan) Castle, Sarıcan Castle, Sadaklı Höyük, Gülşah Castle and Settlement Area, Dikentepe Castle, Mendek Settlement.

Güneykaya Castle is located at an altitude of $2160 \mathrm{~m}, 500 \mathrm{~m}$ west of Güneykaya village, $10 \mathrm{~km}$ west of Eleşkirt district in Ağr1 province. It is at the last point of Tahir Pass that opens to Eleşkirt Plain. It is a very important castle in terms of controlling both Eleşkirt Plain and the Bosphorus.

Çatalpınar Settlement is located $14 \mathrm{~km}$ west of Eleşkirt district in Ağr1 province, $500 \mathrm{~m}$ southwest of Çatalpinar village, at an altitude of $2050 \mathrm{~m}$. The settlement spread over a very large area is $230 \mathrm{~m}$ in the north-south direction and $100 \mathrm{~m}$ in the east-west direction.

Çatalpinar Rock Shelter is located at an altitude of $1960 \mathrm{~m}, 600 \mathrm{~m}$ southwest of Çatalpinar village, 14 $\mathrm{km}$ west of Eleşkirt district in Ağr1 province. The fact that it is at a very steep point made it difficult to work in the center.

Harami Taşlar Castle is located $32 \mathrm{~km}$ northwest of Eleşkirt district in Ağrn province, $5 \mathrm{~km}$ north of Tahir town, at an altitude of $2210 \mathrm{~m}$. It is located on the Erzurum-Ağr1 provincial border. It is on the east side of the old Silk Road that connects Ağr1 to Erzurum. The castle controls the valley to its north.

Tahir Castle is located at an altitude of $2210 \mathrm{~m}, 500 \mathrm{~m}$ southwest of Tahir town, $32 \mathrm{~km}$ northwest of Eleşkirt district in Ağrn province. The castle is on a natural rock just west of the village, east of the Erzurum-Ağr1 highway, at a point that will keep the region under control.

Sarican Castle is located at an altitude of $2140 \mathrm{~m}, 500 \mathrm{~m}$ south of Sarican village, $18 \mathrm{~km}$ west of Eleşkirt district in Ağr1 province. It is an important castle built to control the road, just west of the Erzurum-Ağrn road.

Sadaklı Mound is located at an altitude of $1730 \mathrm{~m}, 100 \mathrm{~m}$ south of Sadaklı village, $7 \mathrm{~km}$ southeast of Eleşkirt district in Ağr1 province. It was previously determined and on 03.05.2007, it was declared a 1st degree site area by the Erzurum Cultural and Natural Heritage Preservation Regional Board and was taken under protection.

Gülşah Castle and Settlement Area is located $25 \mathrm{~km}$ west of Eleşkirt district in Ağr1 province, $3 \mathrm{~km}$ southwest of Karabacak village, at an altitude of $2430 \mathrm{~m}$. It is one of the highest and most important castles in the region.

Dikentepe Castle is located $18 \mathrm{~km}$ west of Eleşkirt district in Ağn province, $3 \mathrm{~km}$ north of Sarıcan village, at an altitude of $2280 \mathrm{~m}$. It was built to control the Erzurum-Ağr1 highway.

Mendek Settlement is located at an altitude of $2180 \mathrm{~m}, 2 \mathrm{~km}$ northeast of Sarican village, $18 \mathrm{~km}$ northwest of Eleşkirt district in Ağr1 province.

It is understood that the district, which started to be settled since the Late Chalcolithic Age, is quite rich in historical and archaeological terms. During the researches, many ceramic data, which we think are very important in order to enlighten the history of the region, were found. Based on these data, pottery finds belonging to the Early Bronze Age in 9 centers, Early Iron Age in 3 centers, Middle Iron Age in 5 centers, Late Iron Age in 2 centers and Hellenistic Period in 1 center were determined. The water cisterns, rock-stepped sanctuary and altars in the Güneykaya Castle point to the Urartian presence in the region in architectural terms. Almost all of the centers used in the Ancient Age were also used in the Middle Ages. During our studies, processed stone tools, which we think will take the historical past of the district much earlier, were also found. Necessary studies are carried out on these tools. There are traces of illicit excavations in all of the centers identified. In Gülşah Castle, which we consider to be one of the most important castles in the region, it has been understood that a large corral was built by removing a significant part of the castle walls. The work we carried out in the west of Eleşkirt district in 2019 will continue in the future. We think that many more centers, which we think will shed light on the history of the region, will be identified thanks to the surveys. 


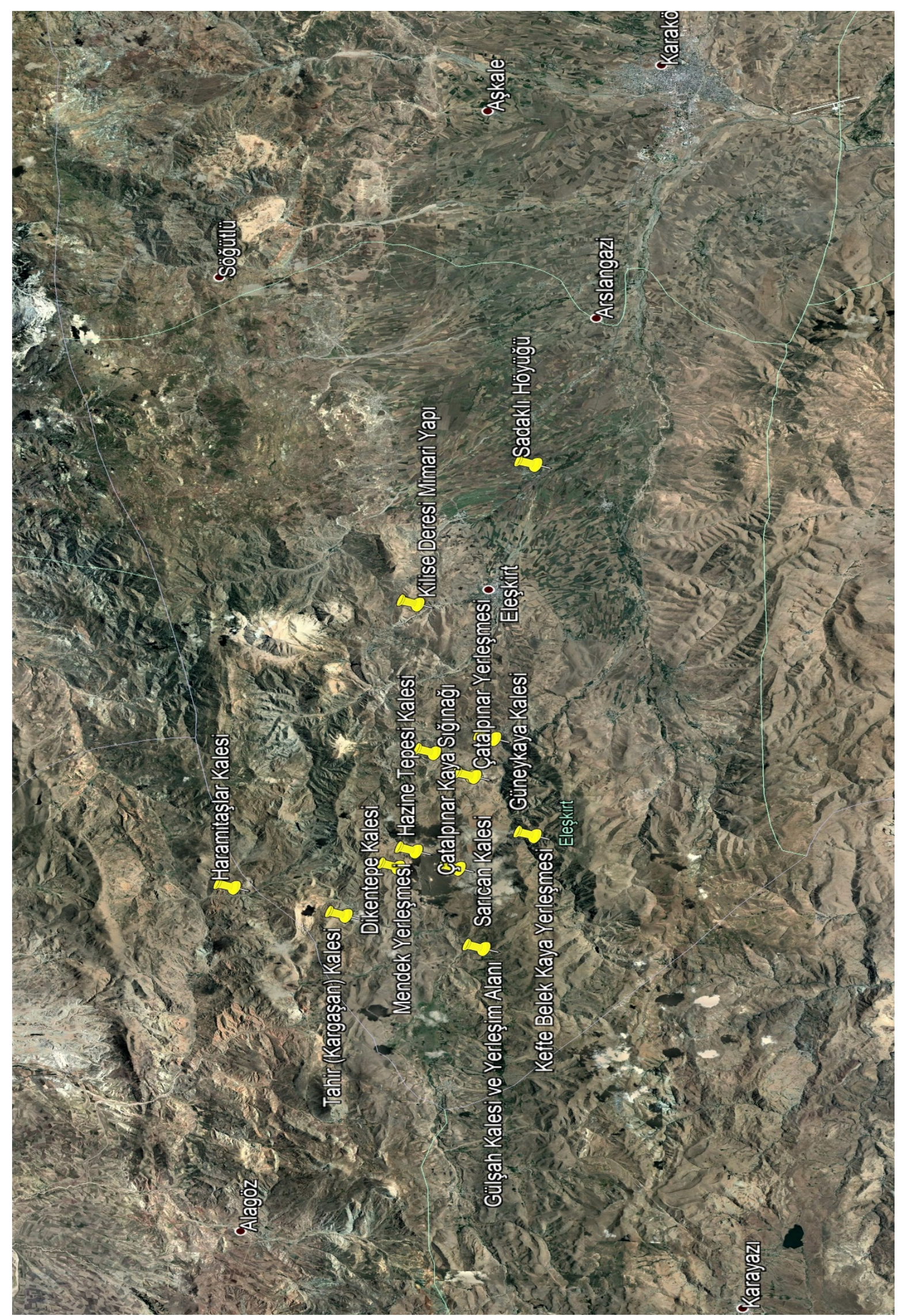

Harita 1. Calışılan Merkęler 


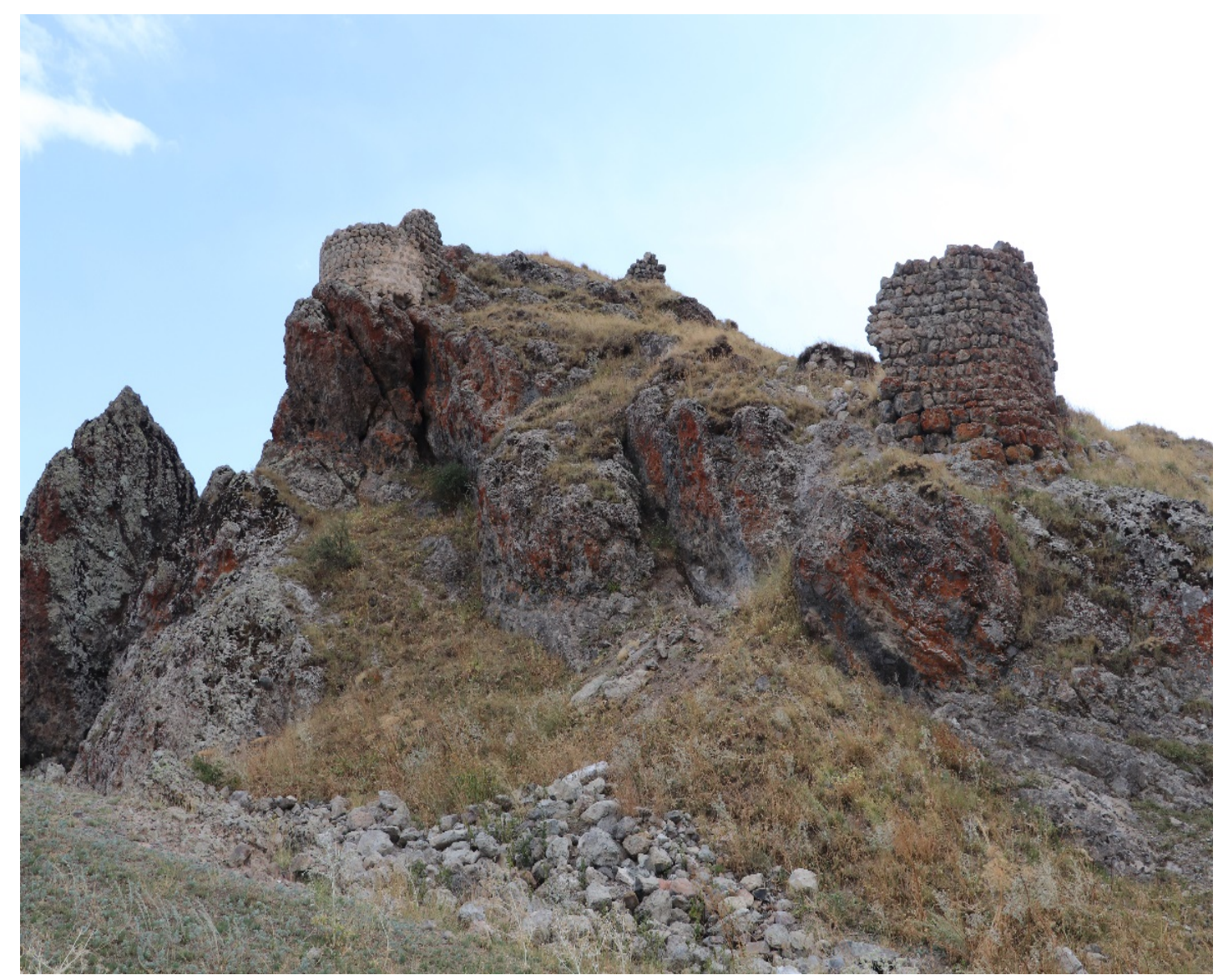

Foto 1. Güneykaya Kalesi Genel Görünümü

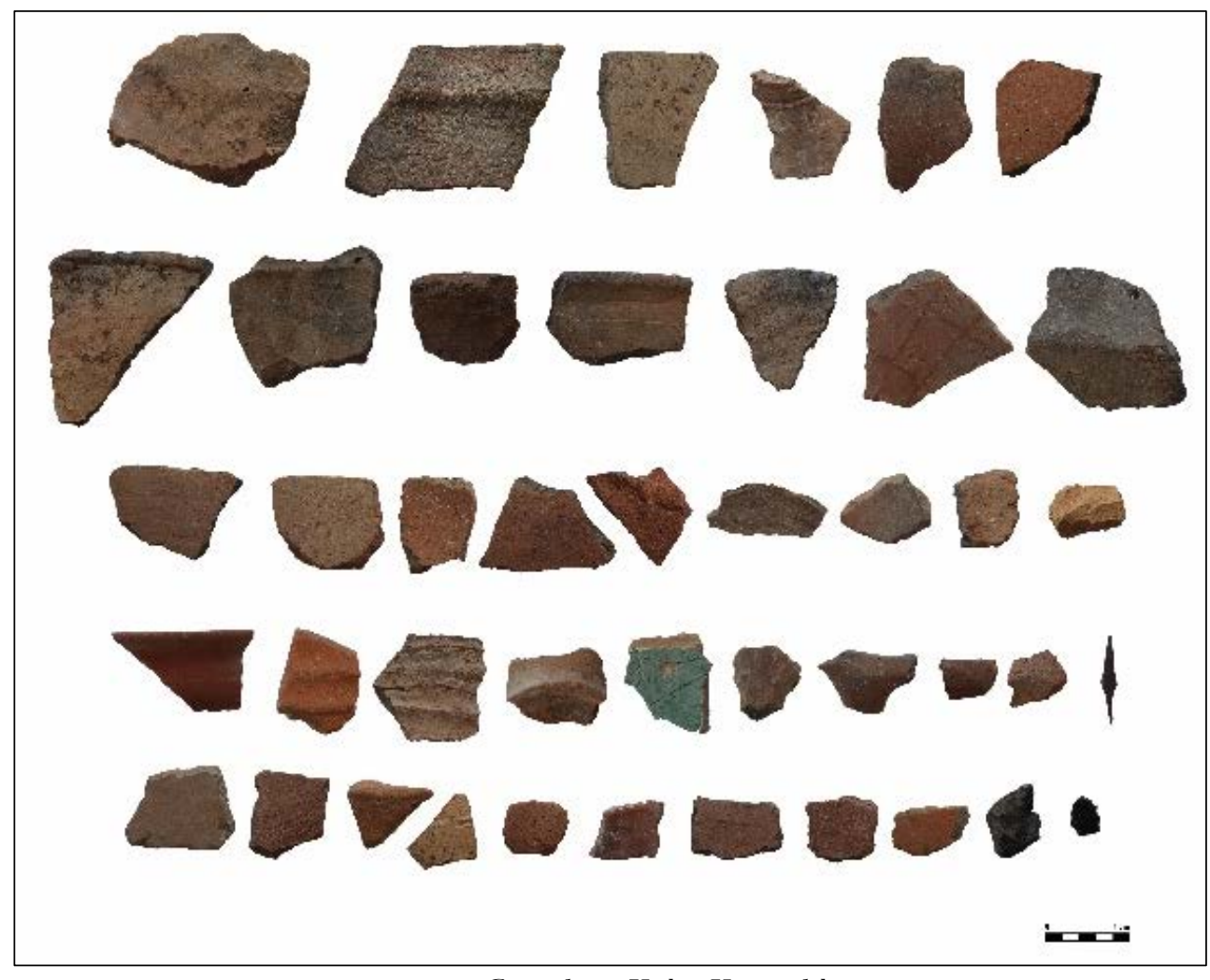

Foto 2. Güneykaya Kalesi Keramikleri 


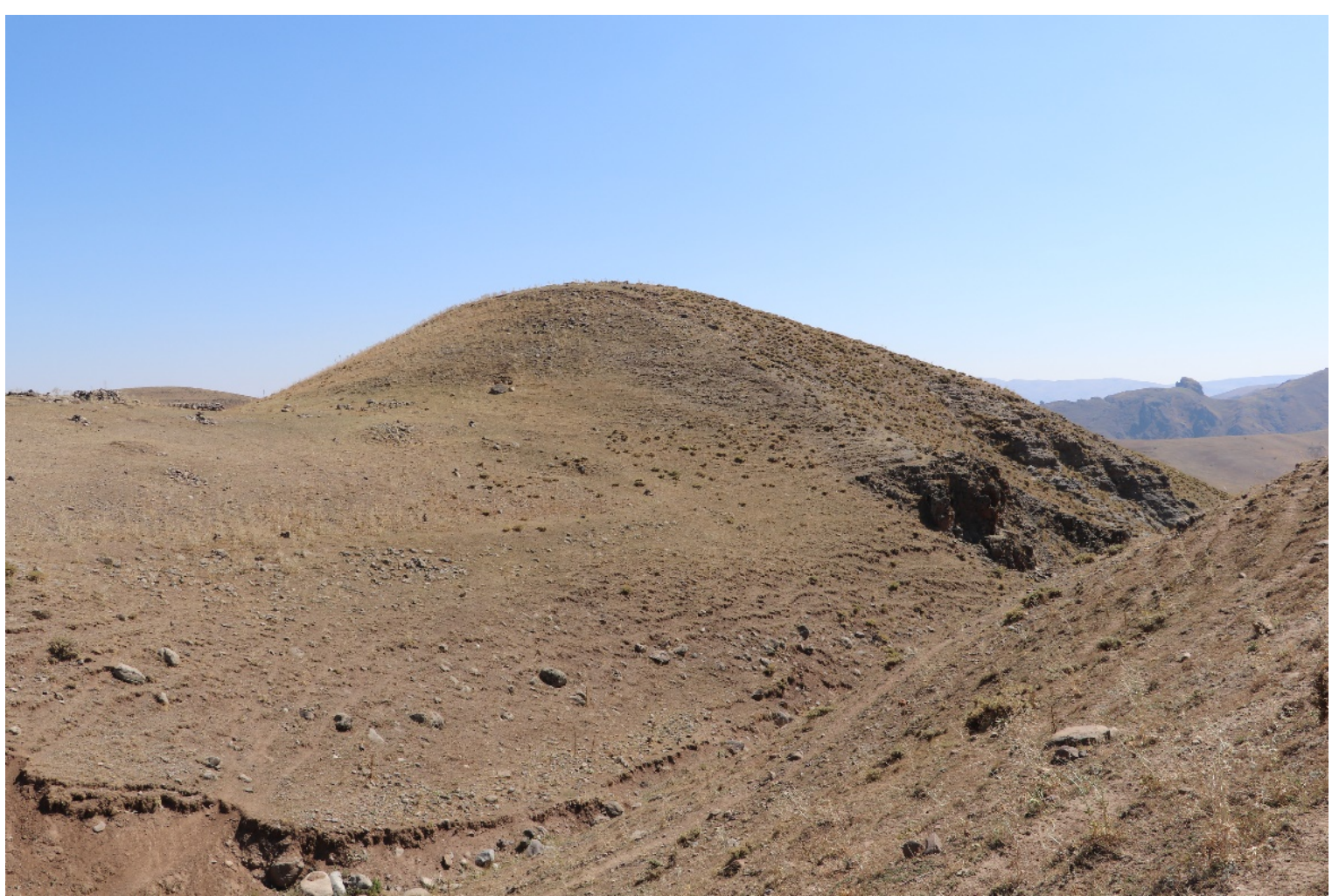

Foto 3. Hazinetepe Kalesi Genel Görünümü

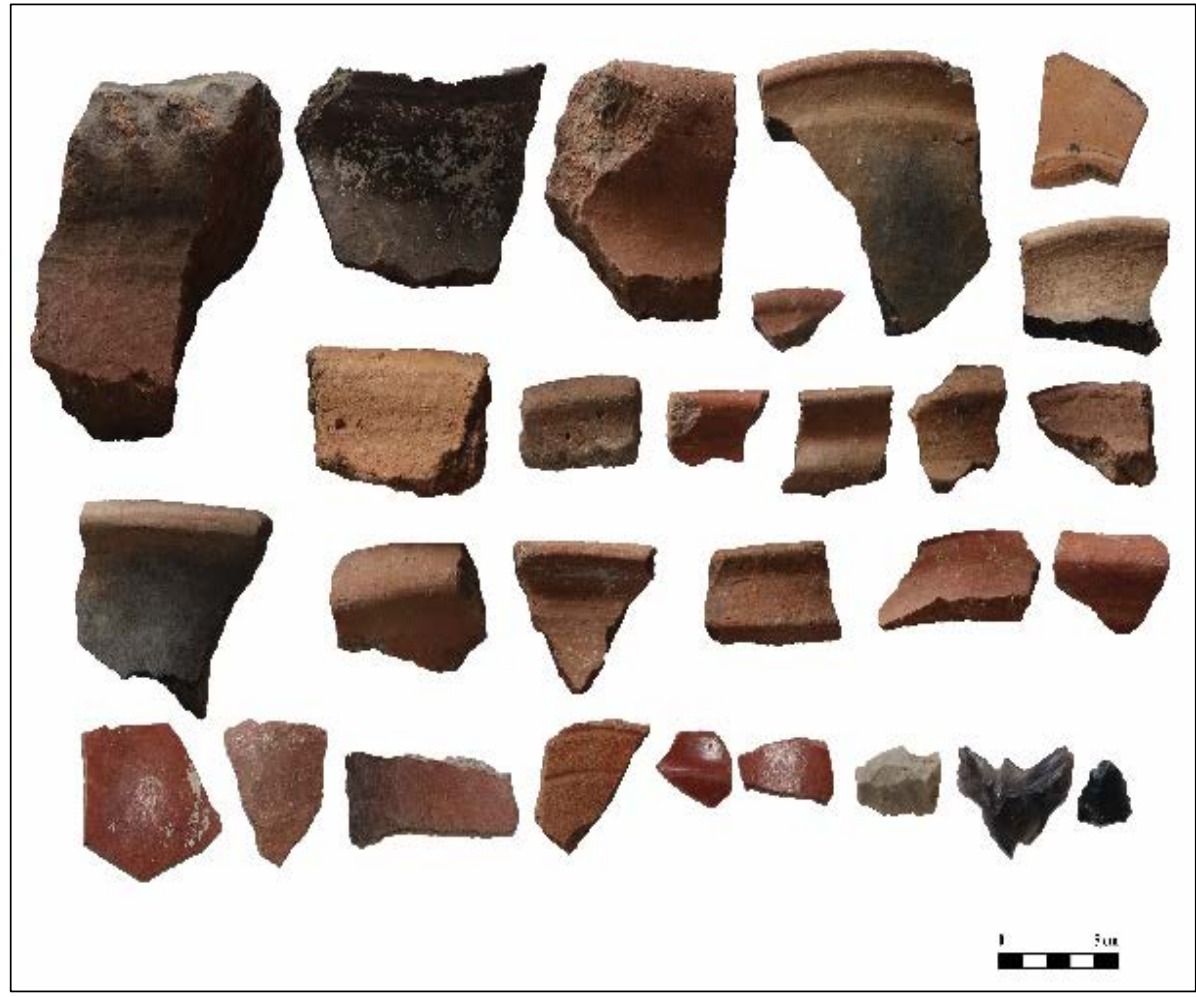

Foto 4. Hazinetepe Kalesi Keramikleri 


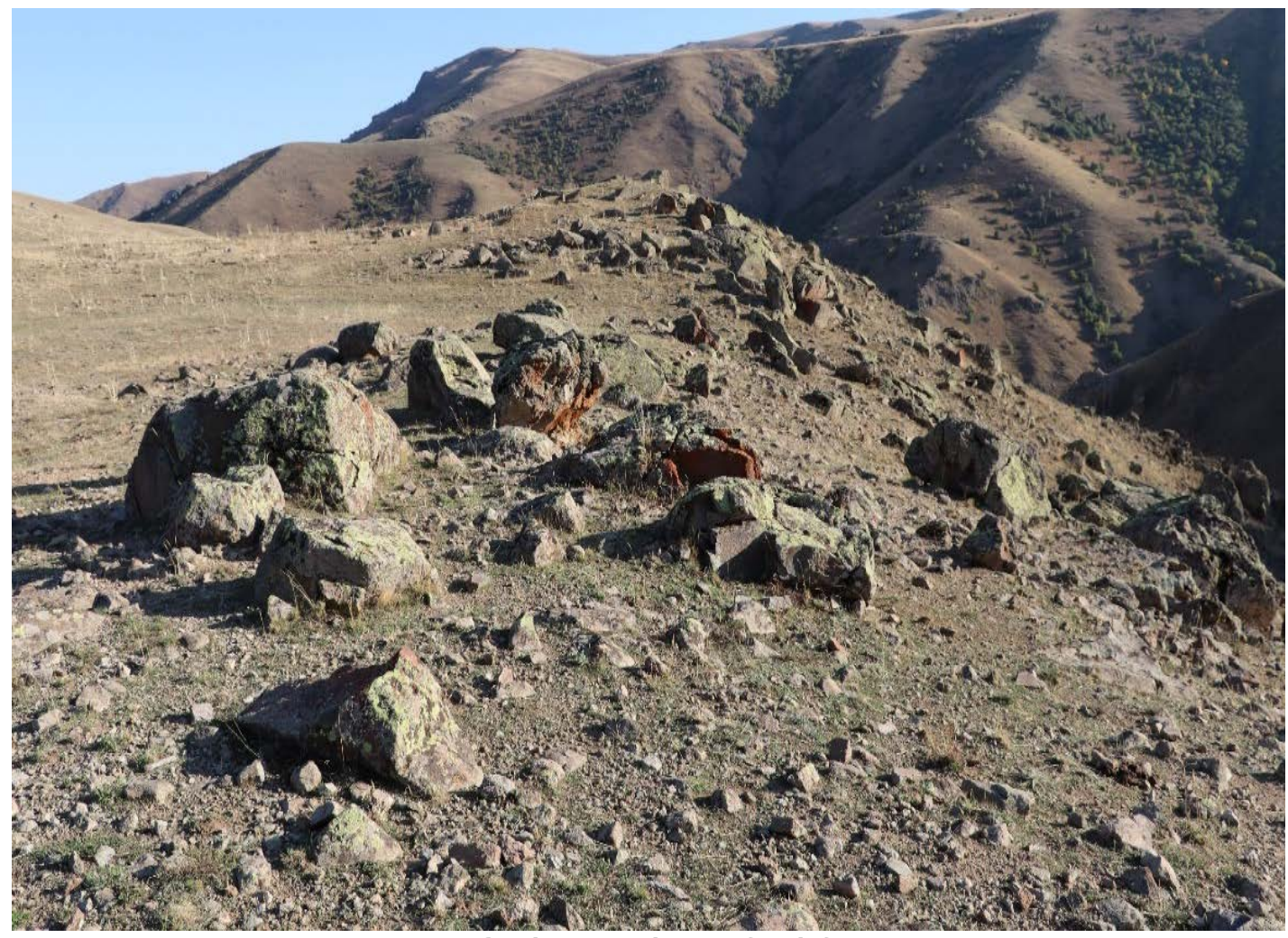

Foto 5. Çatalpinar Yerleșmesi Genel Görünümü

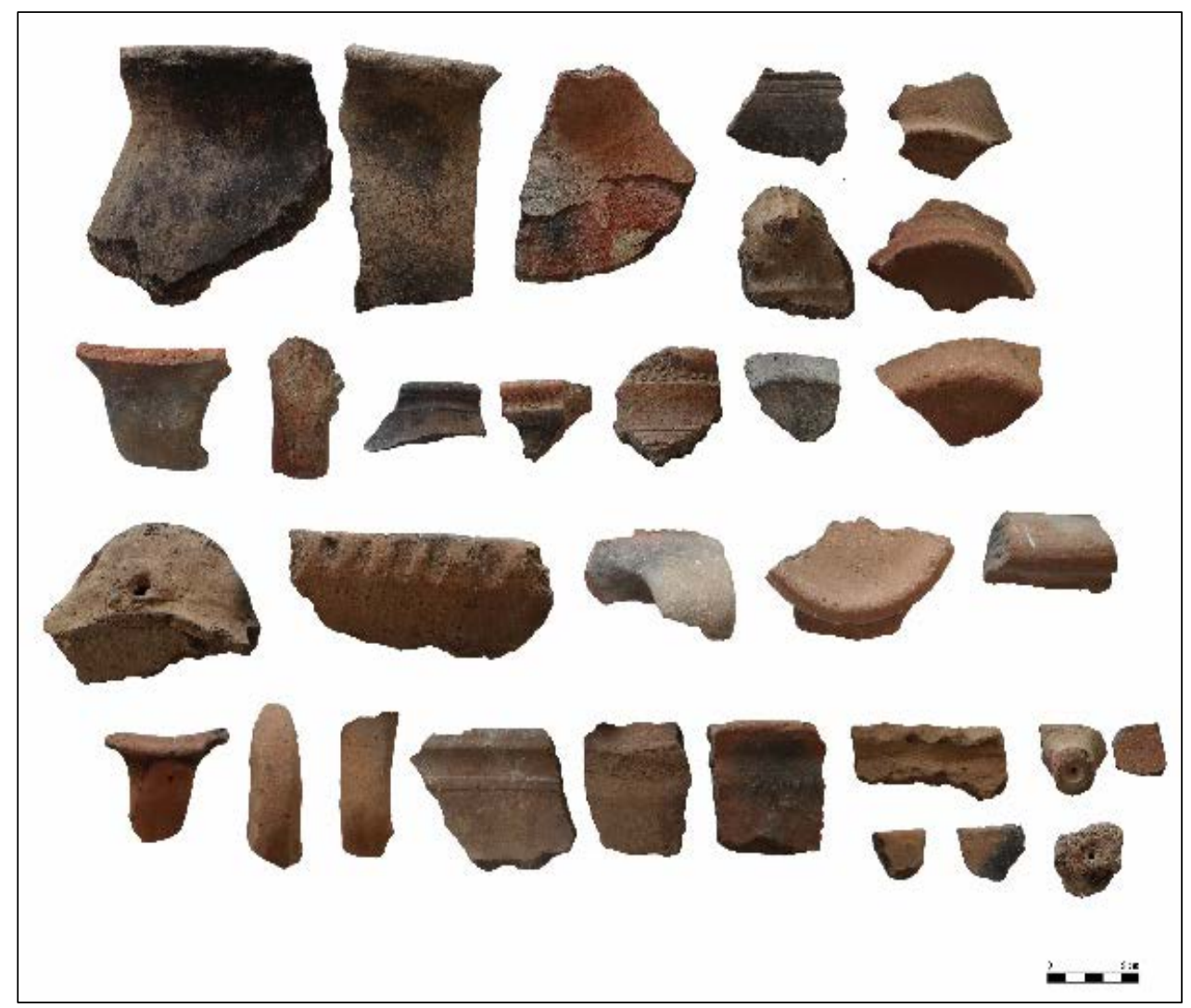

Foto 6. Çatalpinar Yerleșmesi Keramikleri 


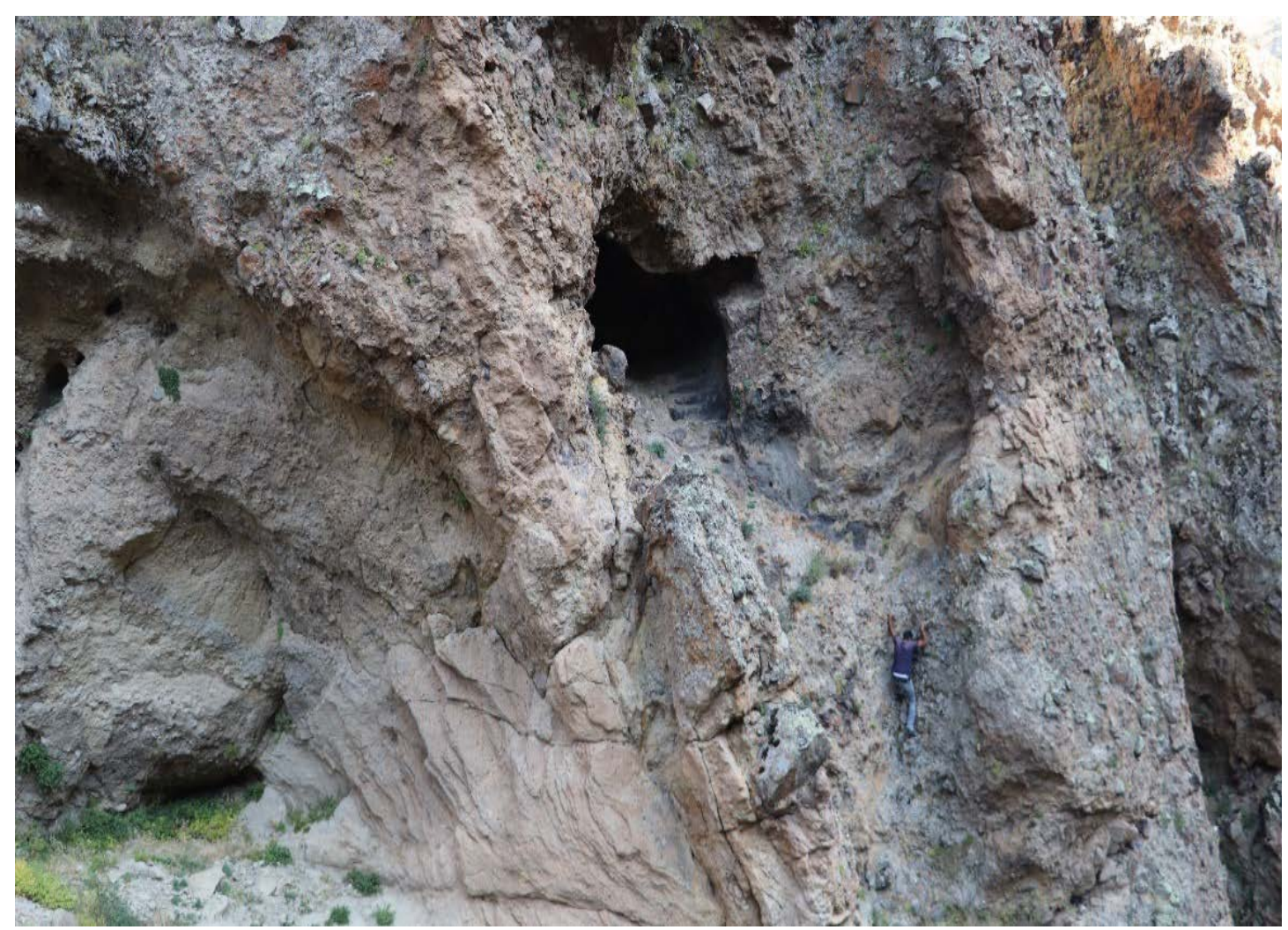

Foto 7. Catalpınar Kaya Siğınağı Genel Görünüm

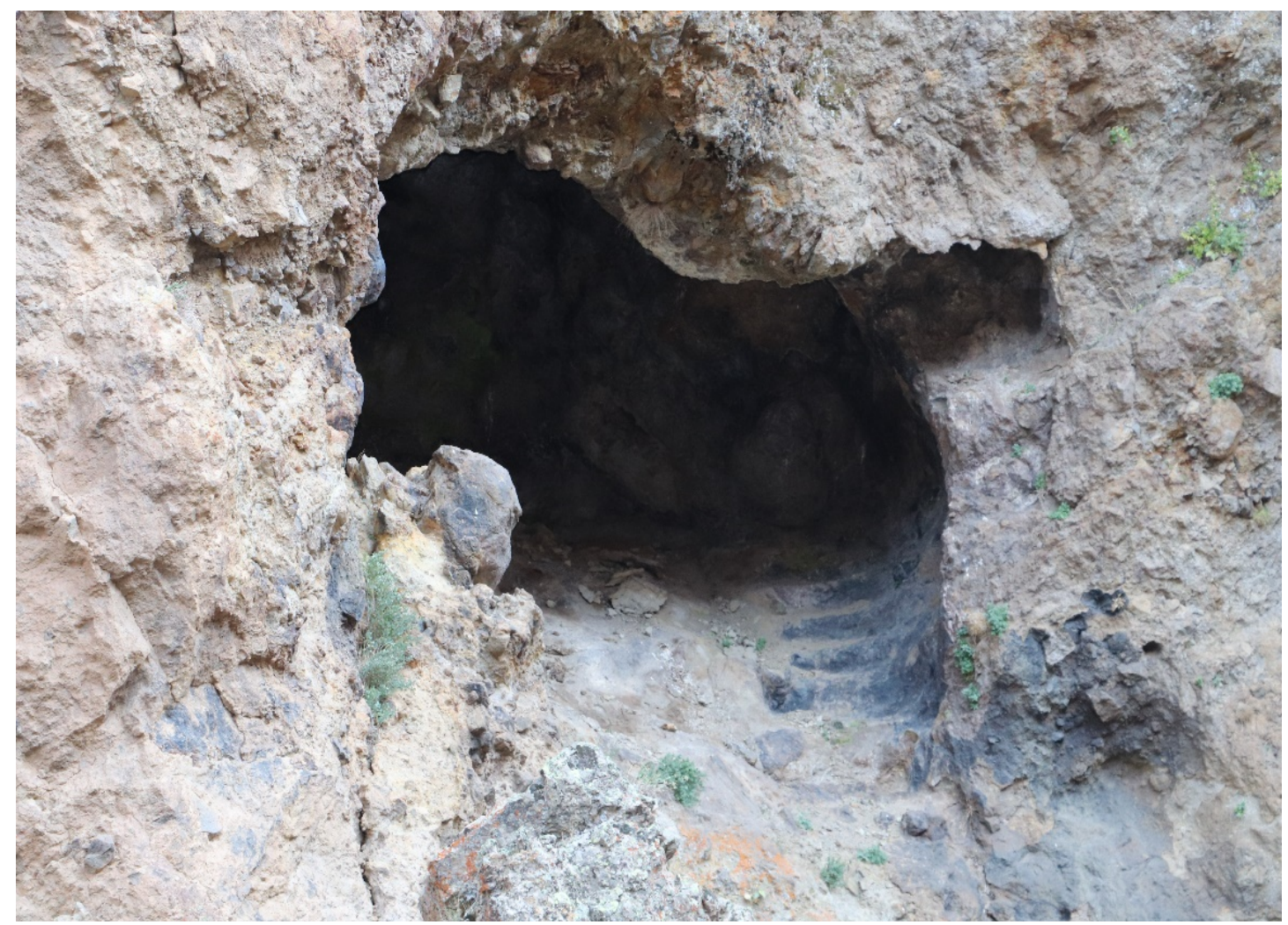

Foto 8. Catalpınar Kaya Siğınağı Genel Görünüm 


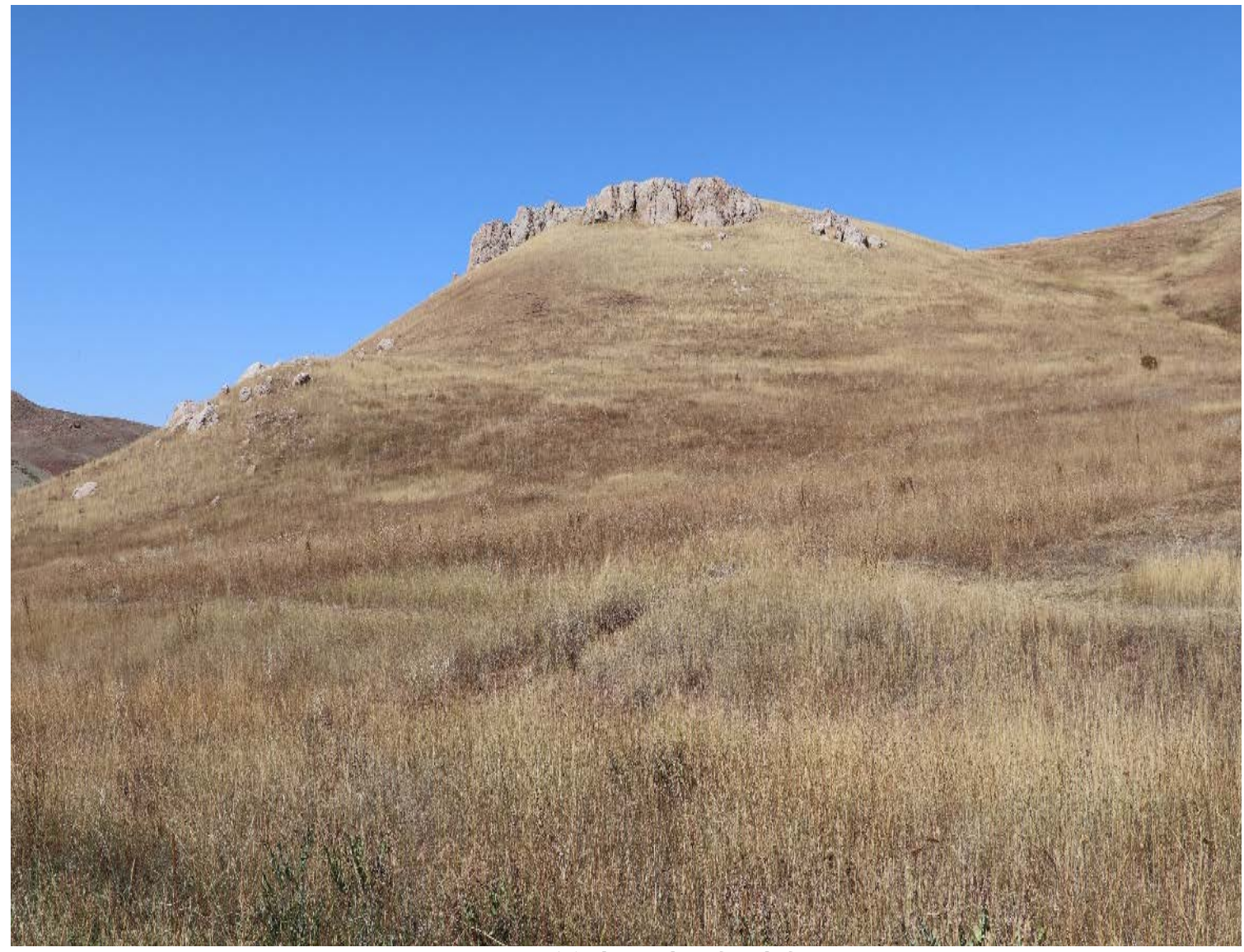

Foto 9. Harami Tașlar Kalesi Genel Görünümü

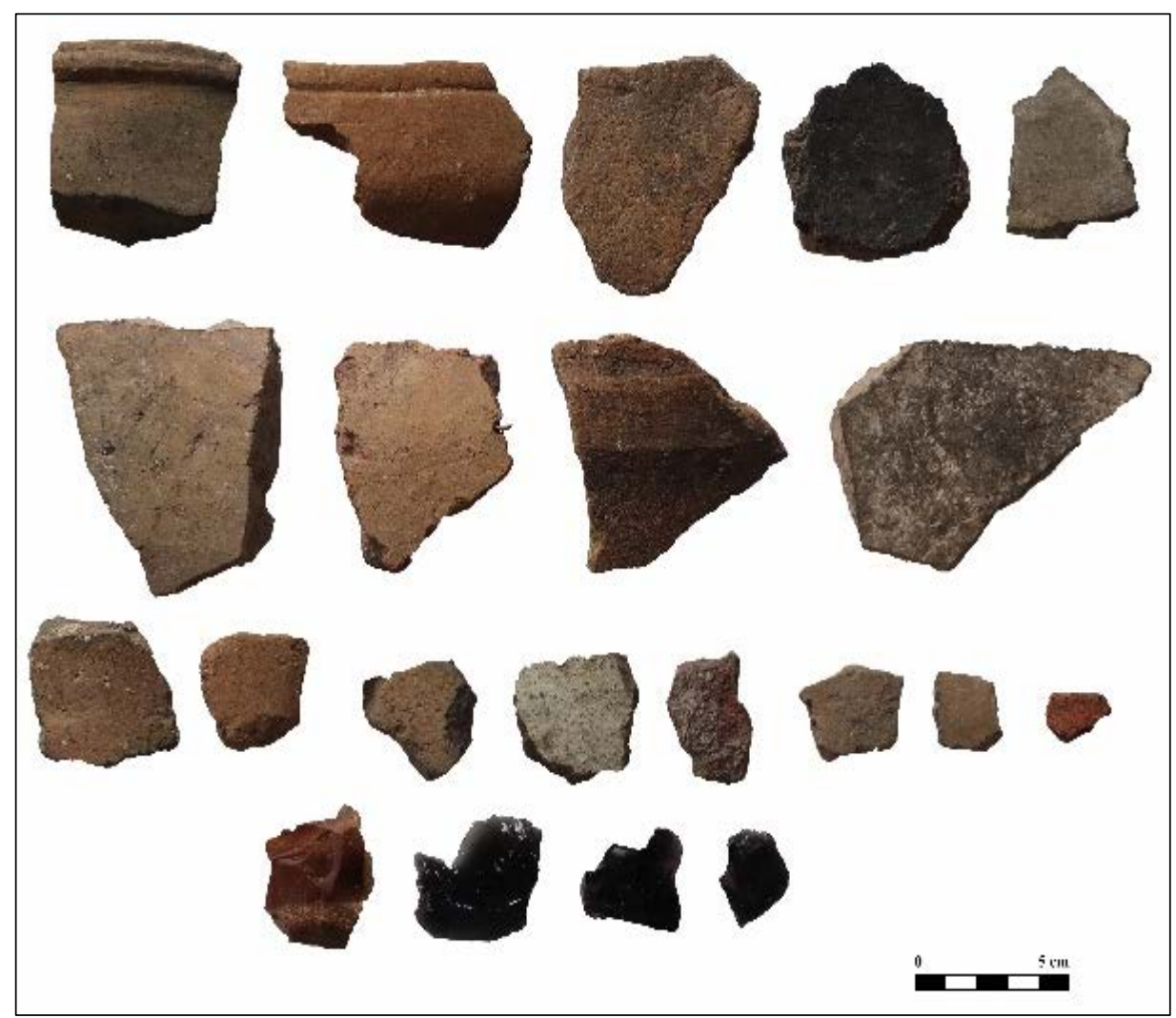

Foto 10. Harami Taşlar Kalesi Keramikleri ve Obsidiyeneri 


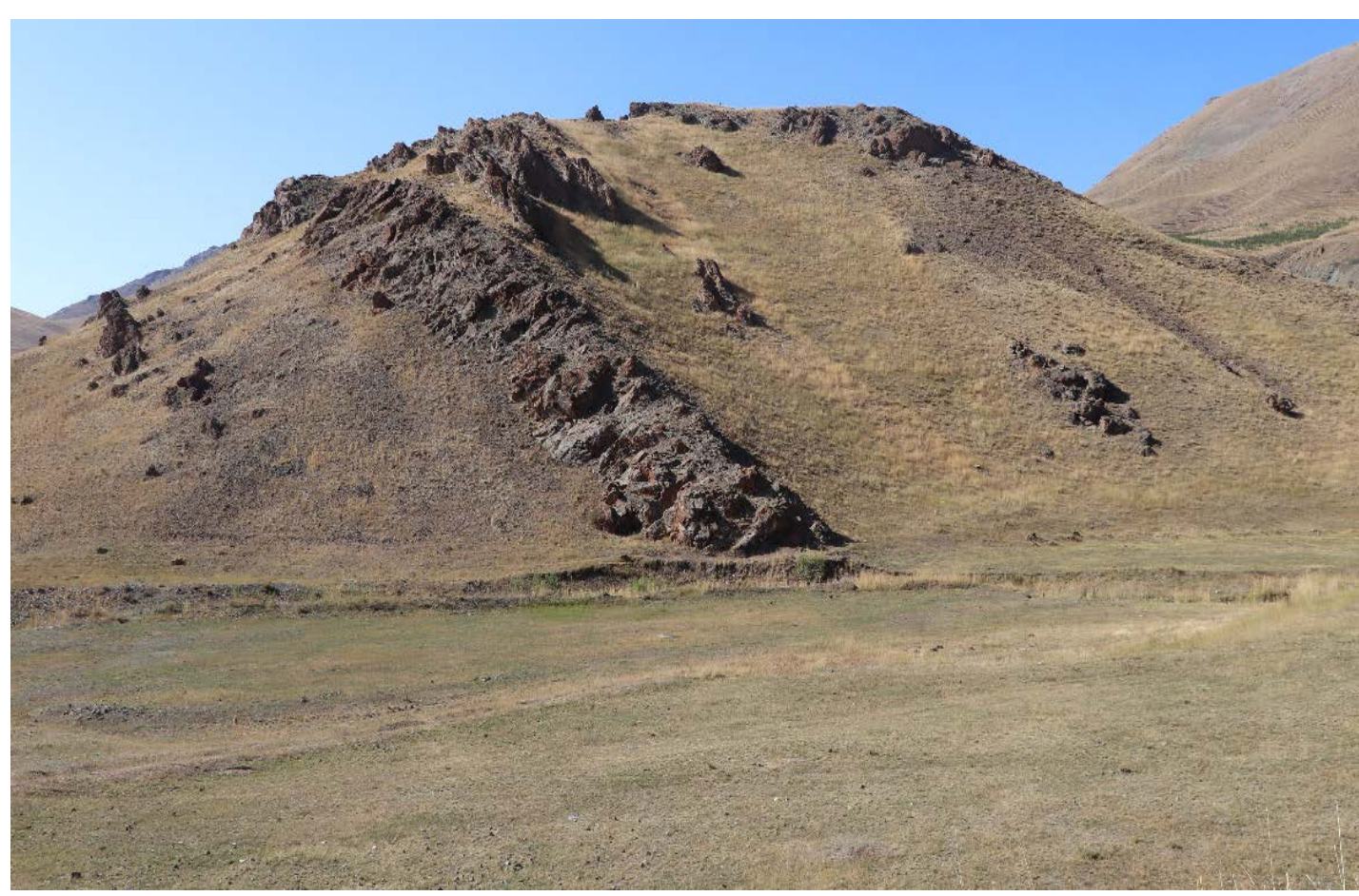

Foto 11. Tahir (Kargasan) Kalesi Genel Görünümü

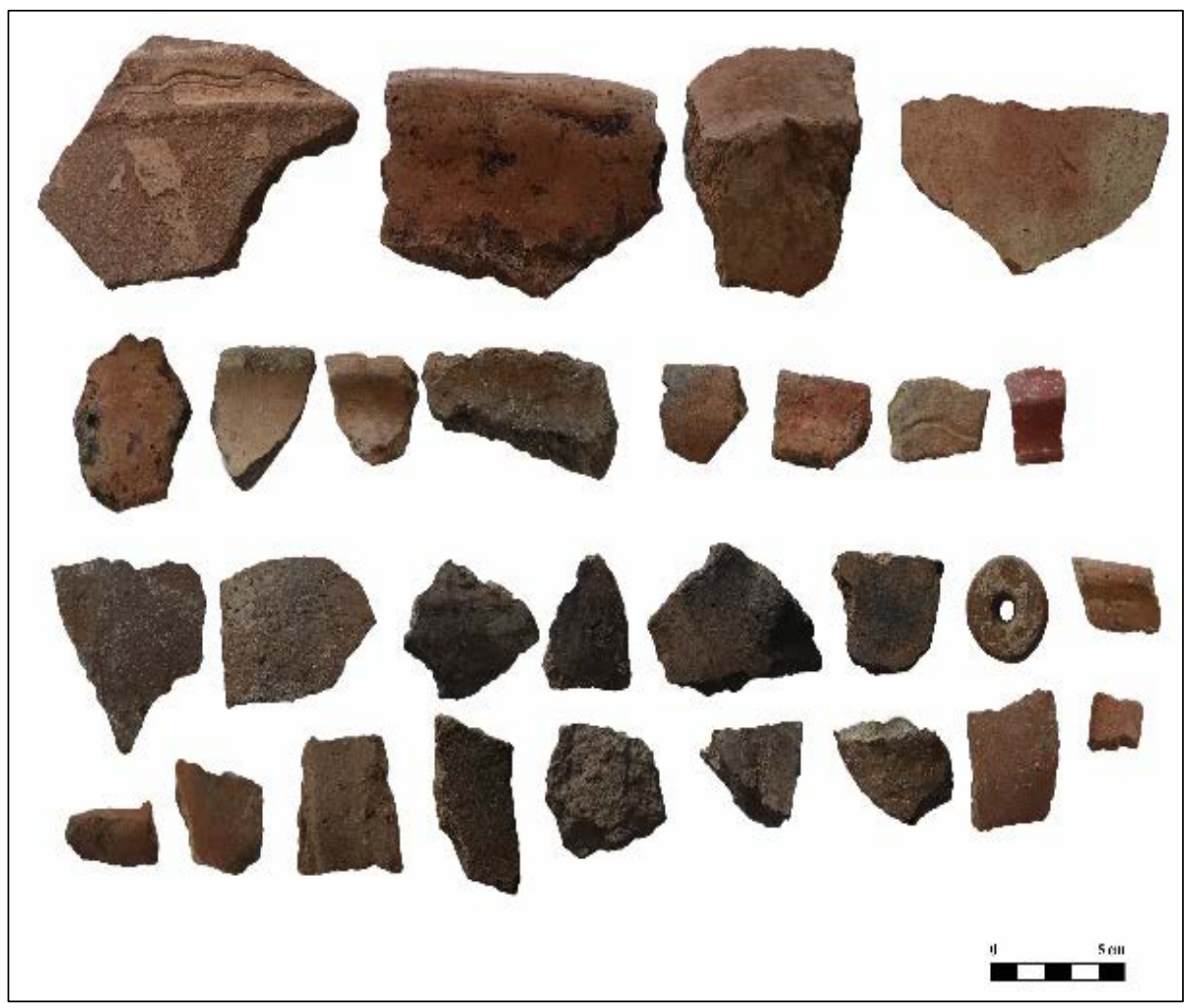

Foto 12. Tahir (Kargasan) Kalesi Keramikleri 


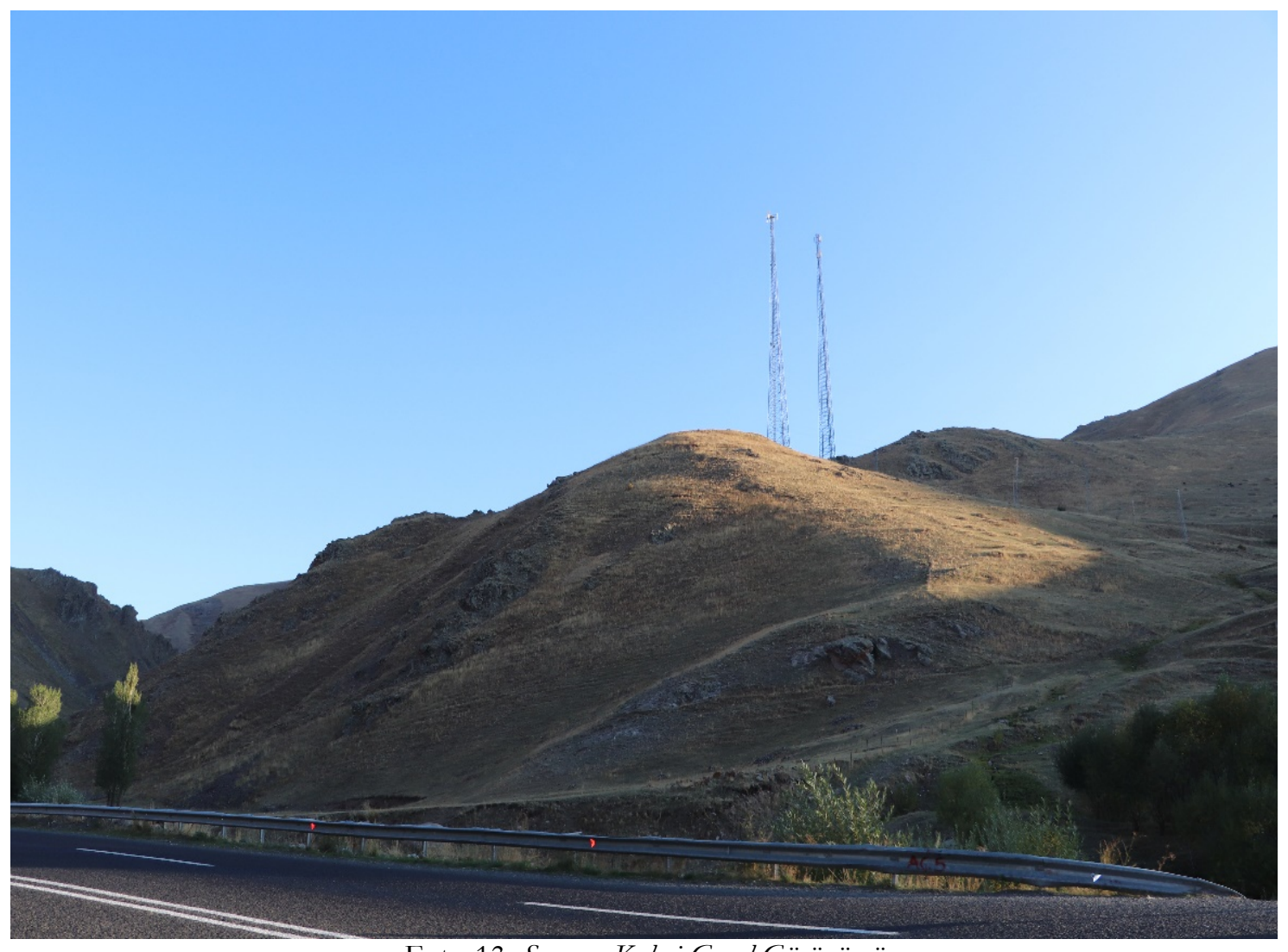

Foto 13. Sarcan Kalesi Genel Görünümü

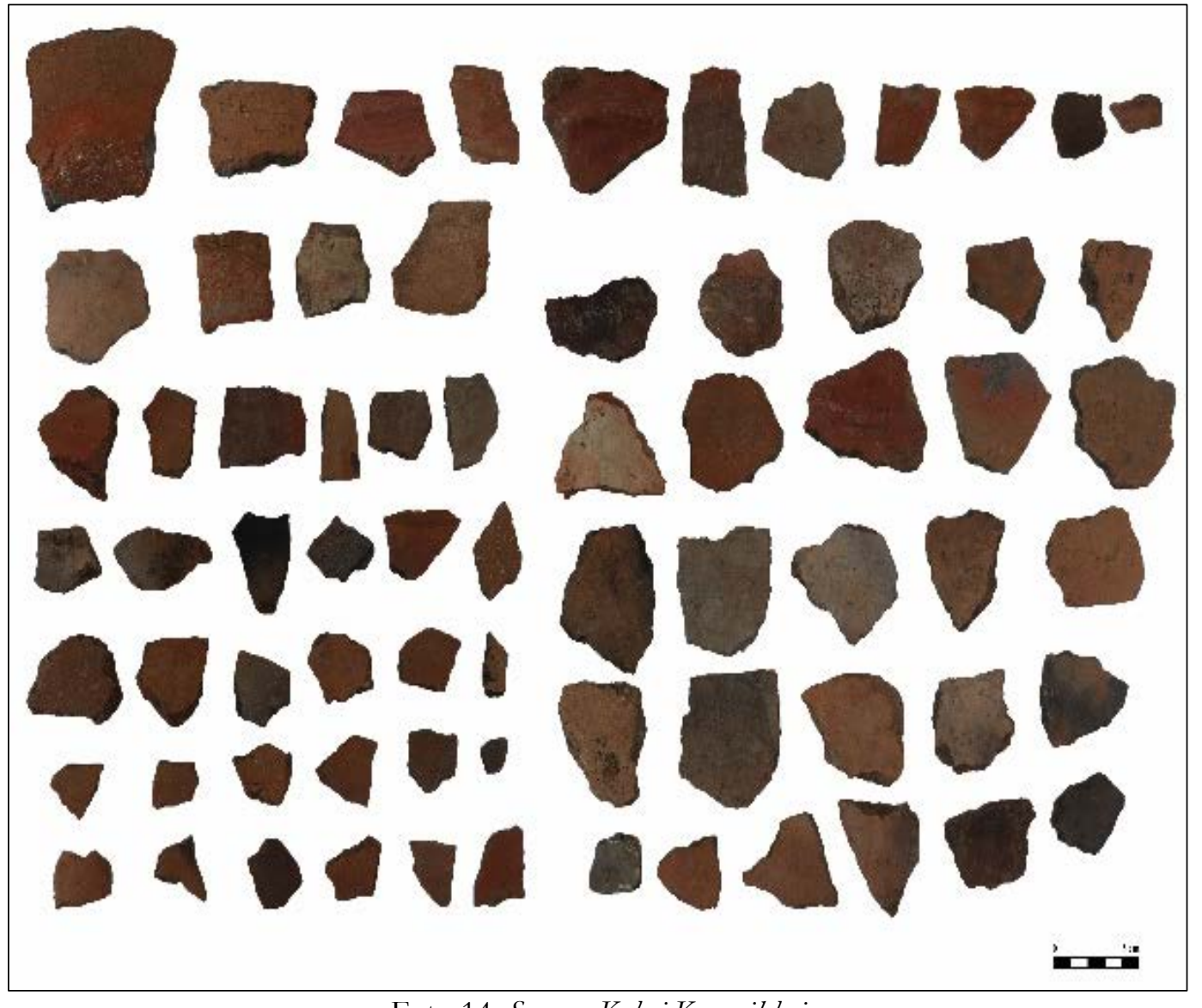

Foto 14. Sarcan Kalesi Keramikleri 


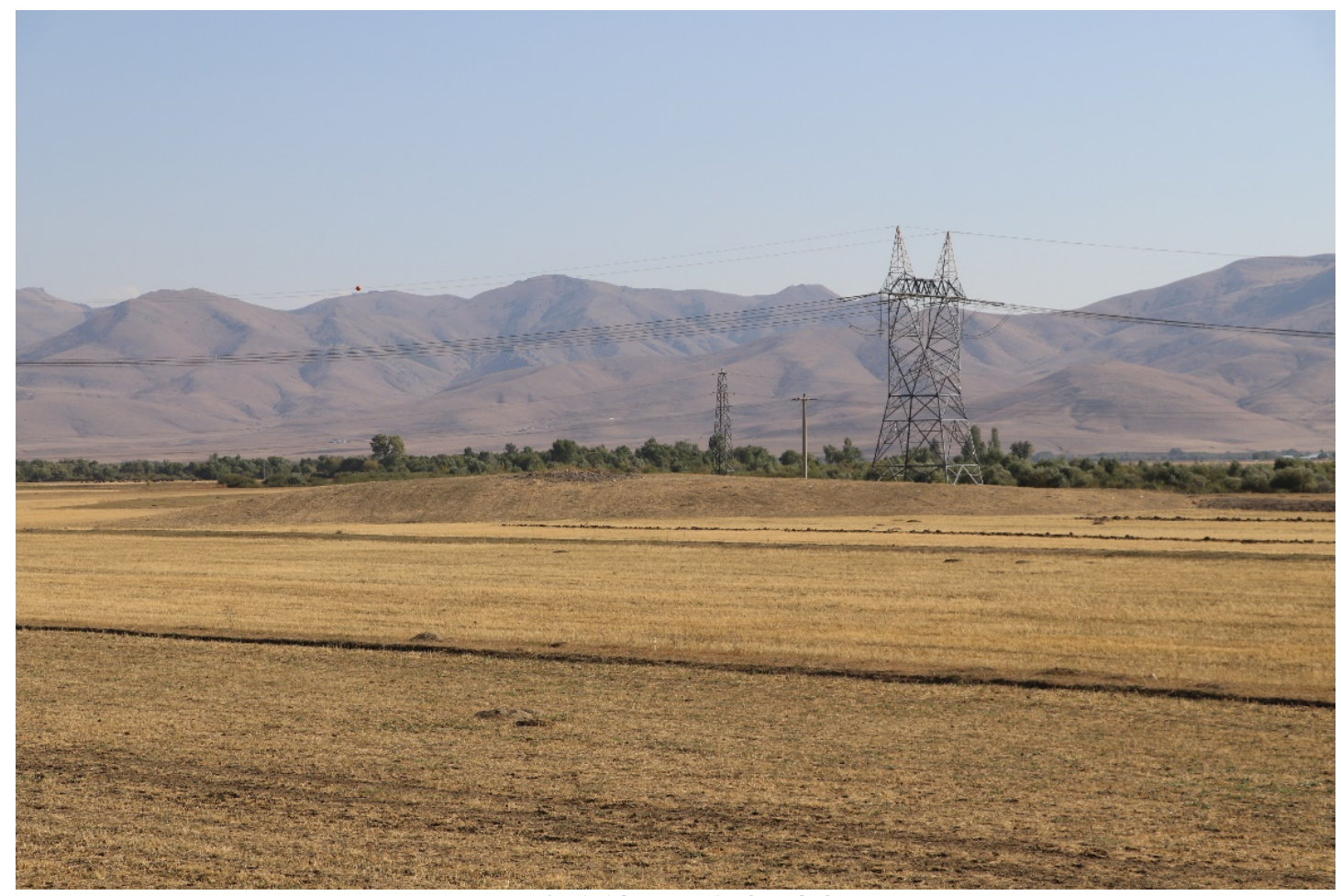

Foto 15. Sadakh Höyük Genel Görünümü

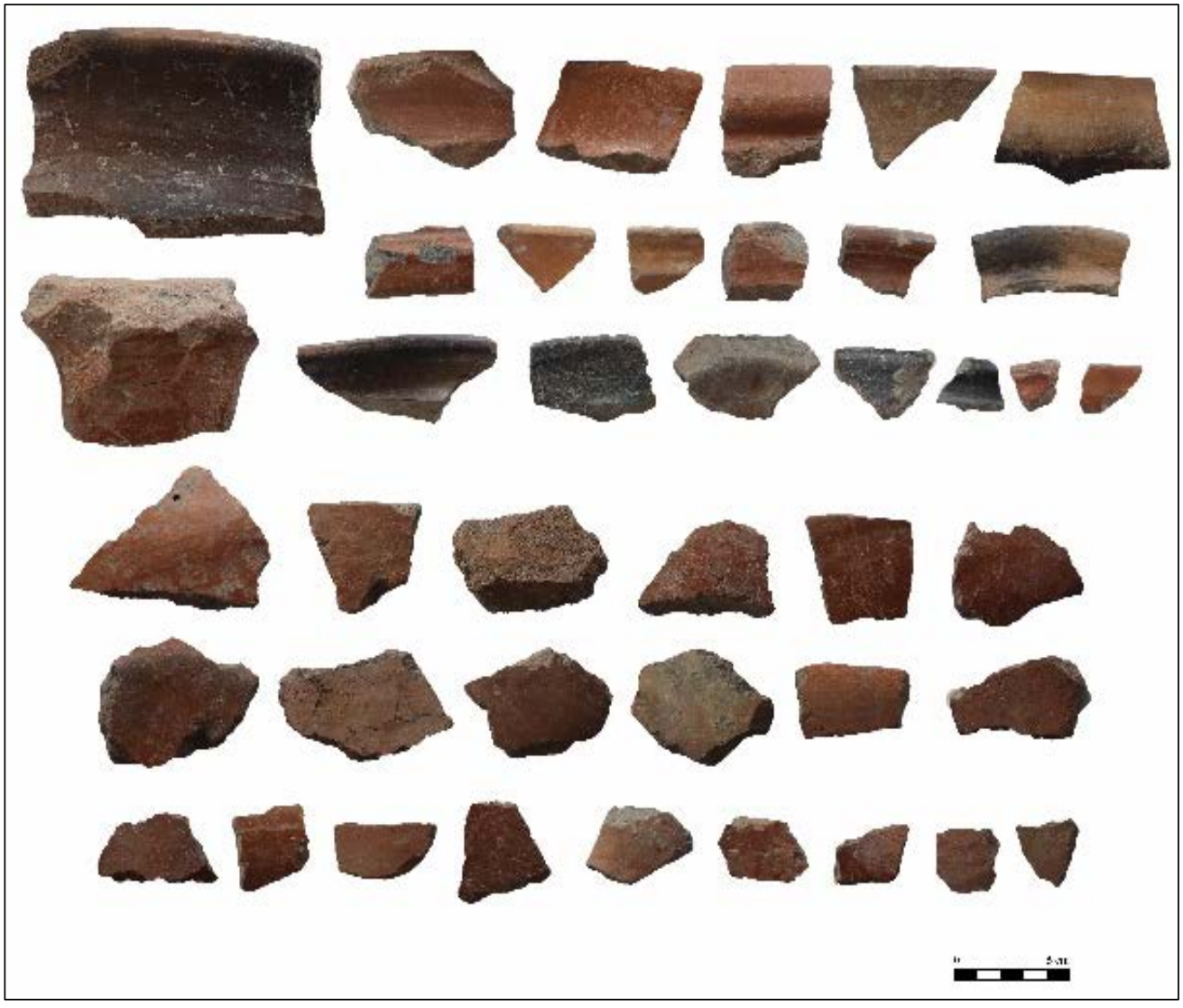

Resim 16. Sadakh Höÿ̈̈k Keramikleri 


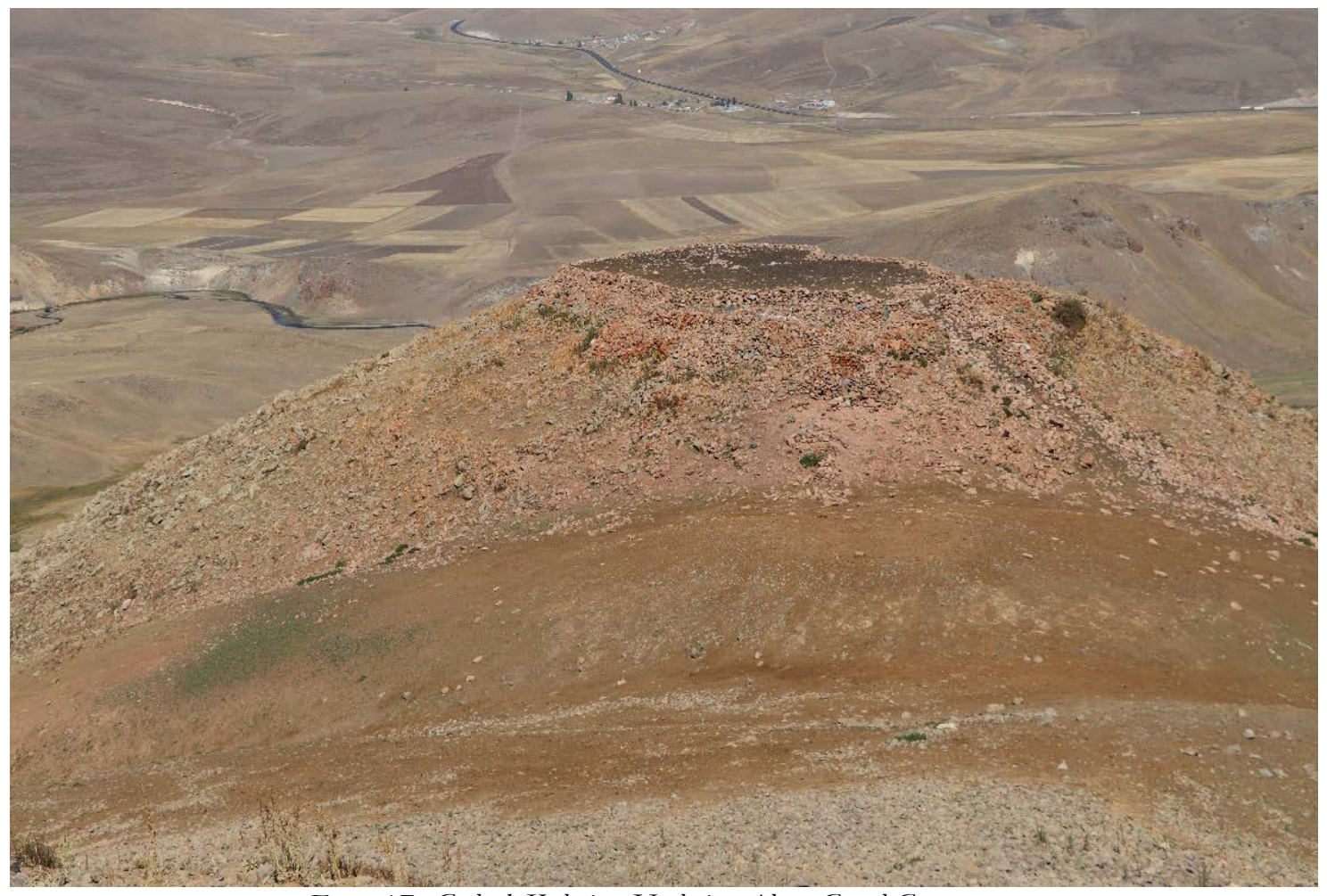

Foto 17. Gülşab Kalesi ve Yerleşim Alanı Genel Görünümü

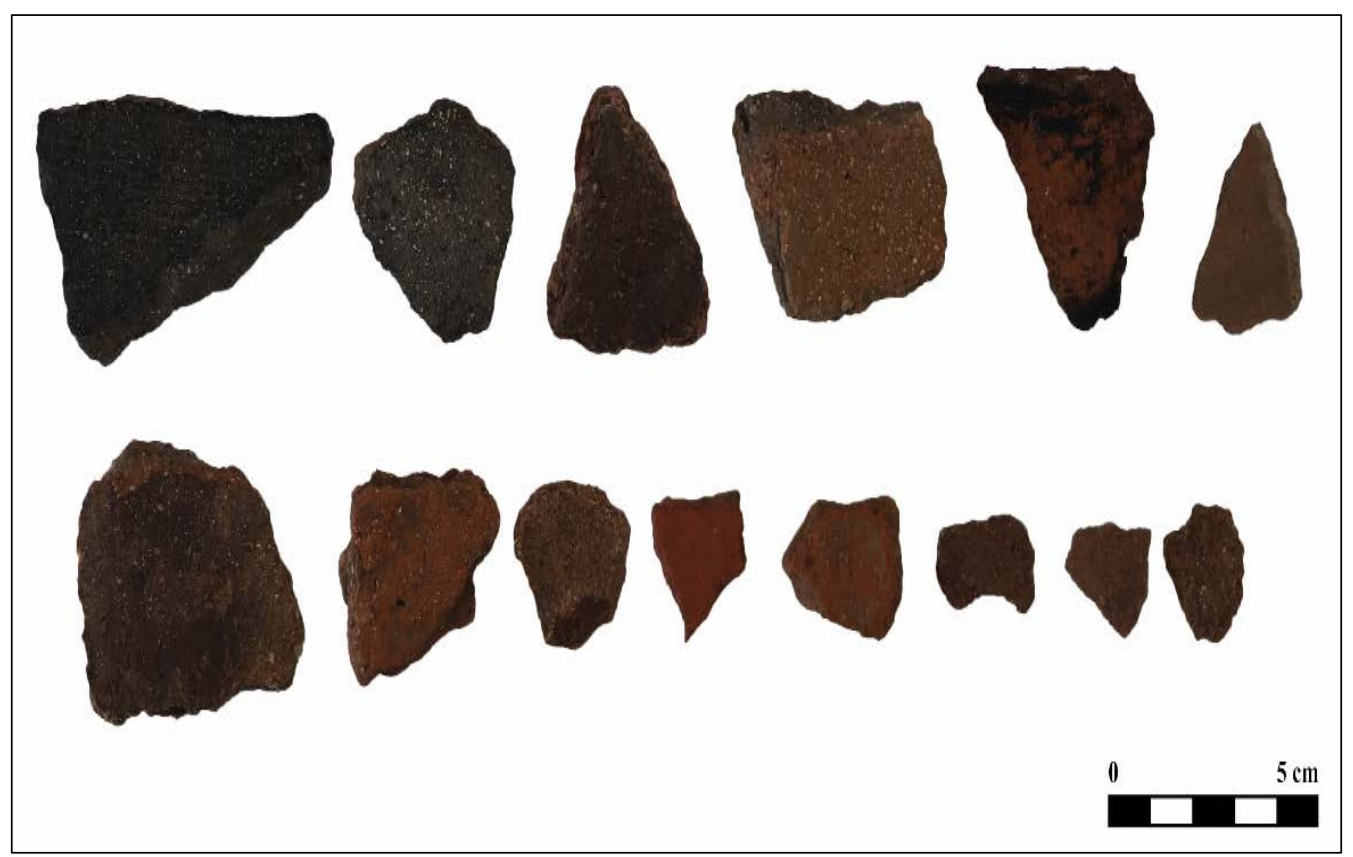

Foto 18. Gülşah Kalesi ve Yerleşim Alan Keramikleri 


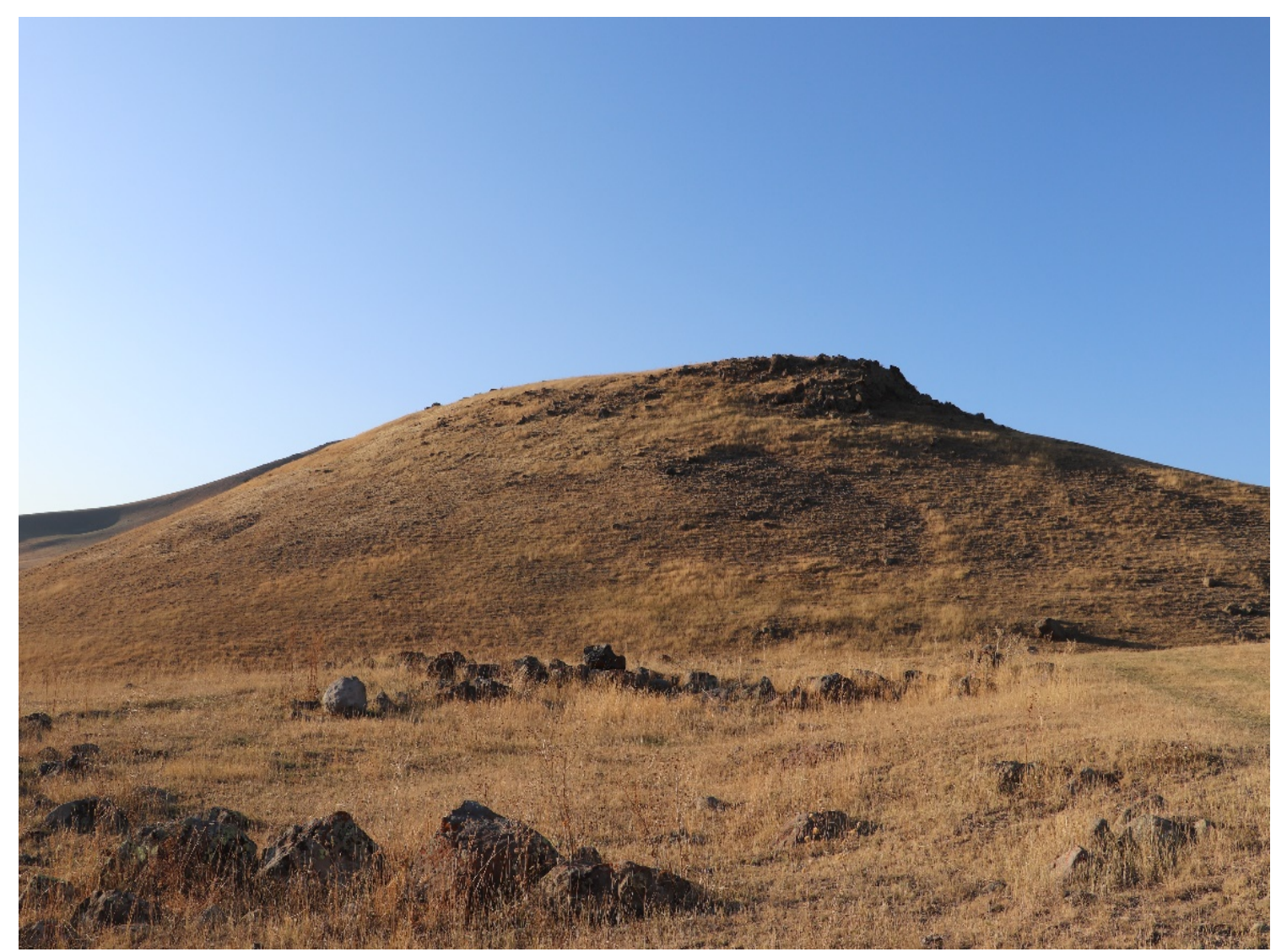

Foto 19. Dikentepe Kalesi Genel Görünümù

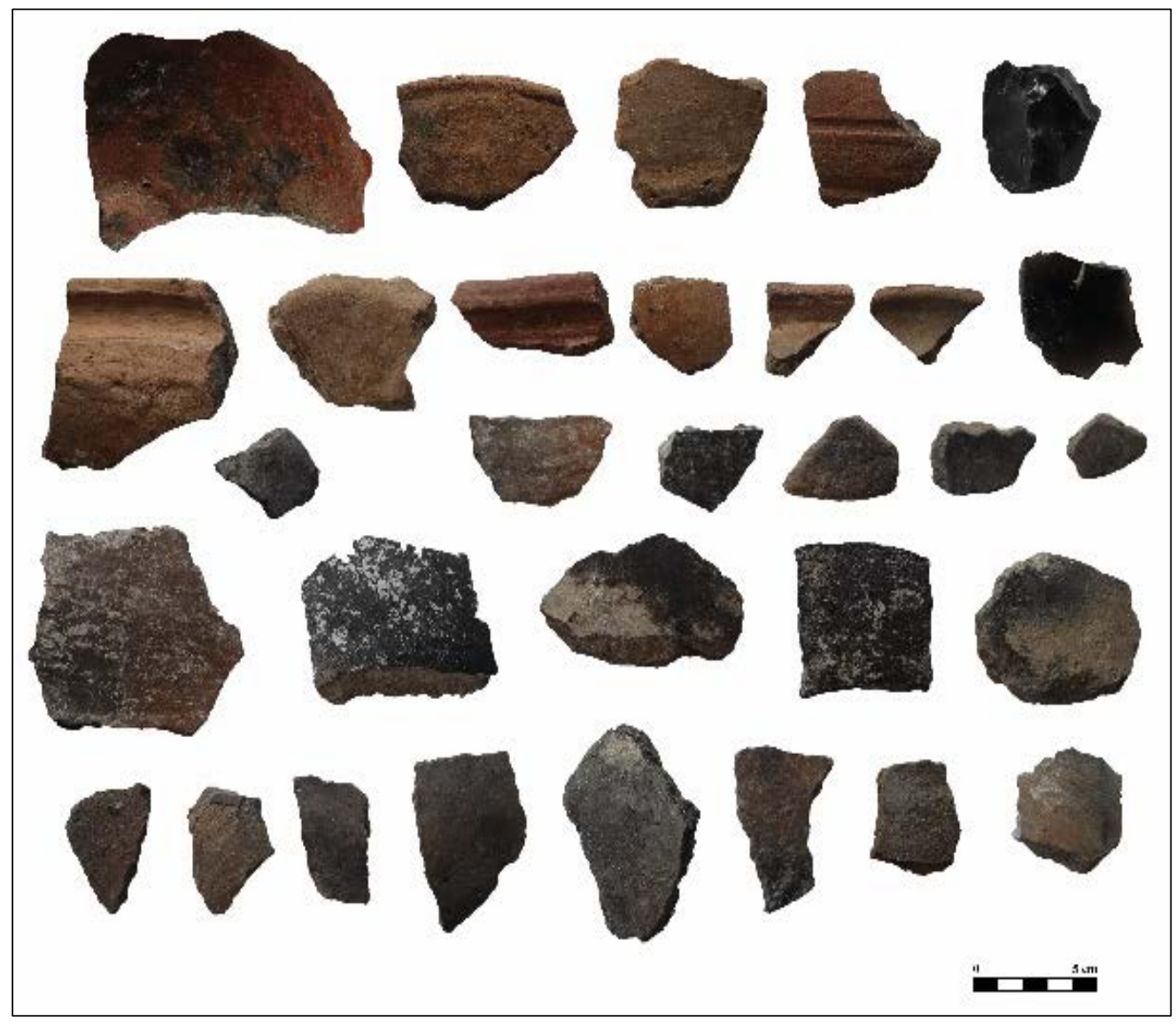

Foto 20. Dikentepe Kalesi Keramikleri 


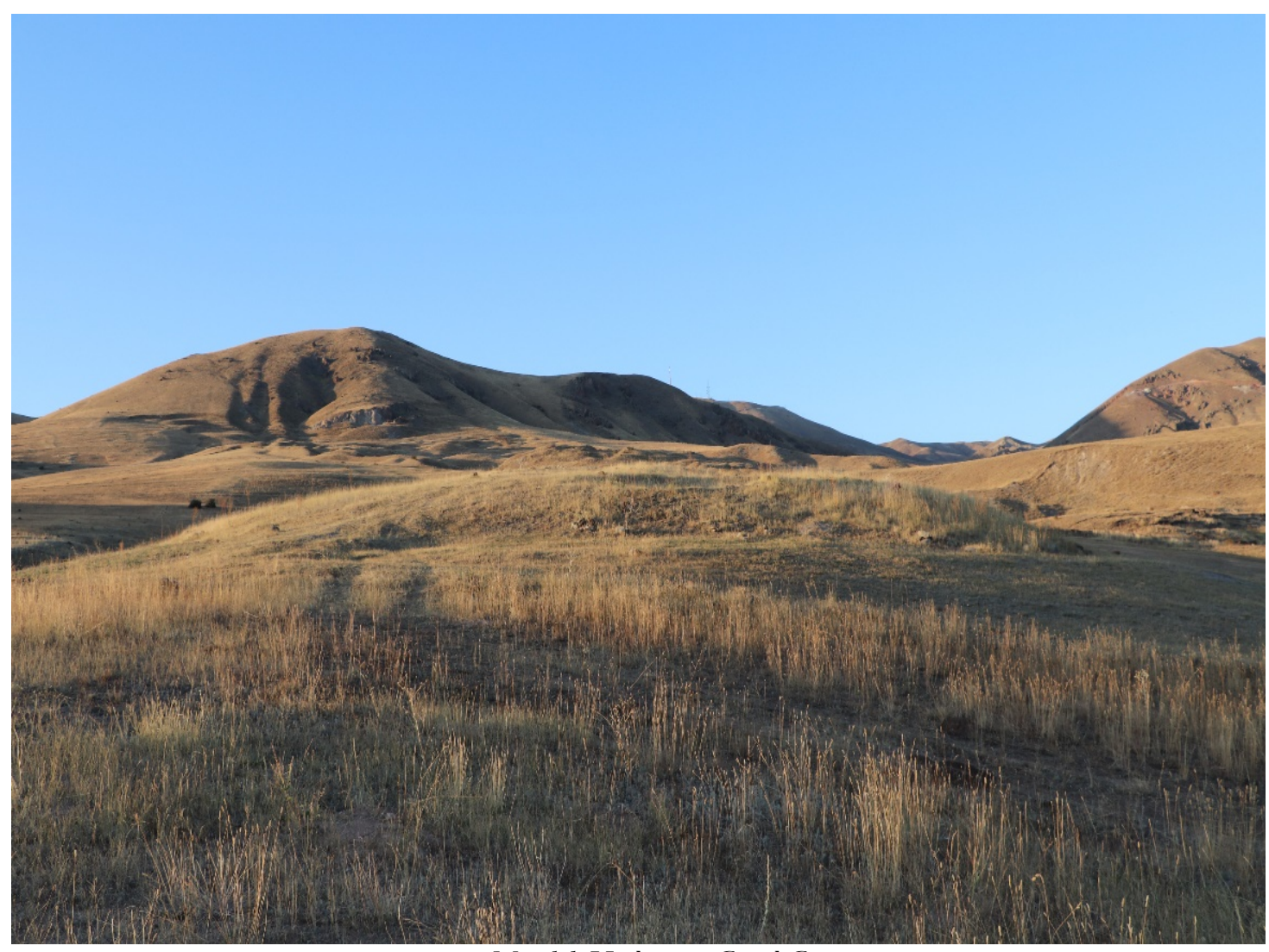

Foto 21. Mendek Yerleşmesi Genel Görünümü

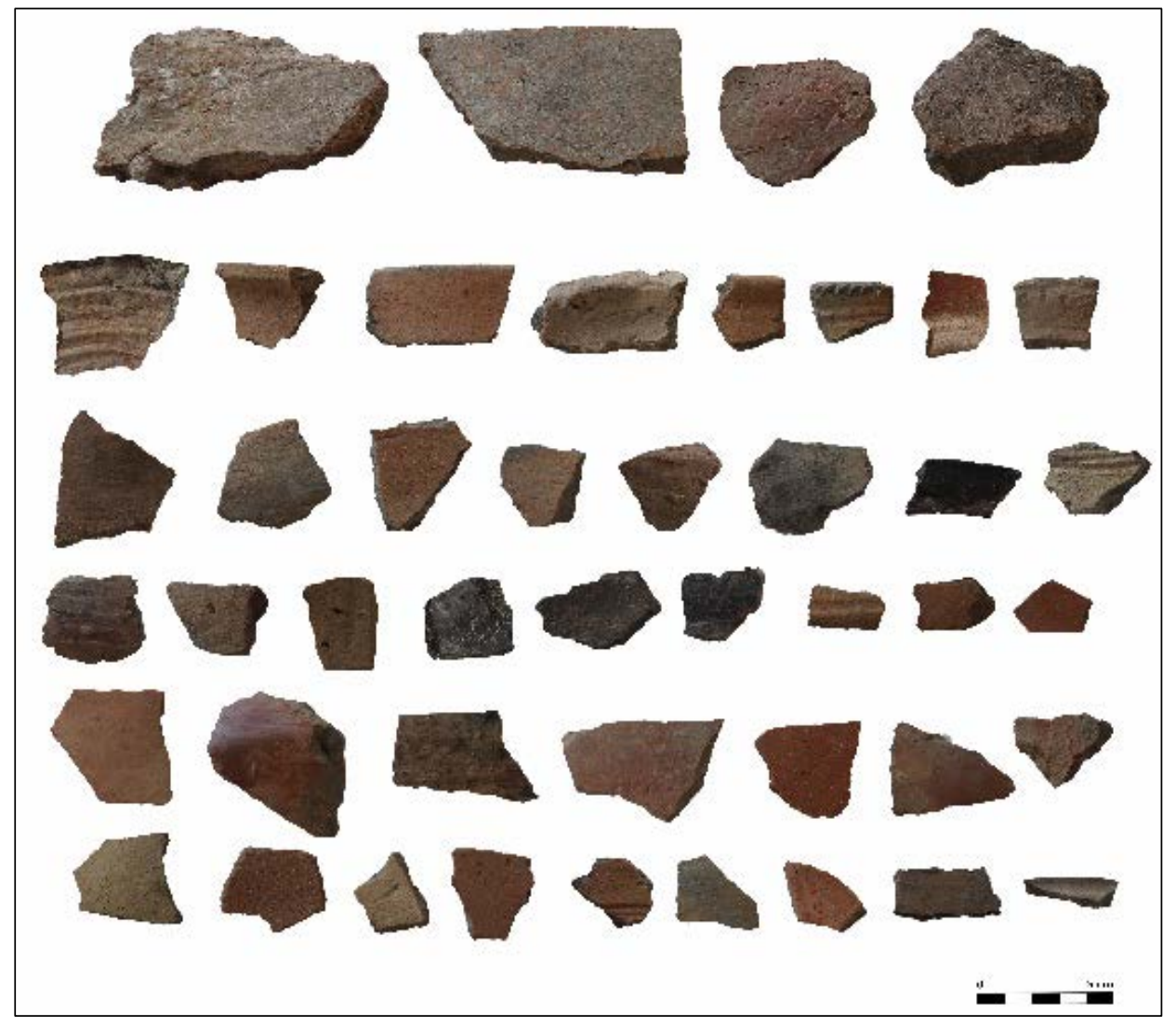

Foto 22. Mendek Yerleșmesi Keramikleri 